\title{
Interleukin (IL)-12 and IL-23 and Their Conflicting Roles in Cancer
}

\author{
Juming Yan, ${ }^{1,2}$ Mark J. Smyth, ${ }^{2,3}$ and Michele W.L. Teng ${ }^{1,2}$ \\ ${ }^{1}$ Cancer Immunoregulation and Immunotherapy Laboratory, QIMR Berghofer Medical Research Institute, \\ Herston 4006, Queensland, Australia \\ ${ }^{2}$ School of Medicine, University of Queensland, Herston 4006, Queensland, Australia \\ ${ }^{3}$ Immunology in Cancer and Infection Laboratory, QIMR Berghofer Medical Research Institute, Herston 4006, \\ Queensland, Australia \\ Correspondence: michele.teng@qimrberghofer.edu.au
}

\begin{abstract}
The balance of proinflammatory cytokines interleukin (IL)-12 and IL-23 plays a key role in shaping the development of antitumor or protumor immunity. In this review, we discuss the role IL-12 and IL-23 plays in tumor biology from preclinical and clinical data. In particular, we discuss the mechanism by which IL-23 promotes tumor growth and metastases and how the IL-12/IL-23 axis of inflammation can be targeted for cancer therapy.
\end{abstract}

$T_{\mathrm{f}}^{\mathrm{h}}$ he recognized interleukin (IL)-12 cytokine family currently consists of IL-12, IL-23, IL-27, and IL-35 and these cytokines play important roles in the development of appropriate immune responses in various disease conditions (Vignali and Kuchroo 2012). They act as a link between the innate and adaptive immune system through mediating the appropriate differentiation of naïve $\mathrm{CD} 4^{+} \mathrm{T}$ cells into various $\mathrm{T}$ helper (Th) subsets and regulating the functions of different effector cell types. IL-12, IL-23, and IL-27 are secreted by activated antigen-presenting cells (APCs), such as dendritic cells (DCs) and macrophages (Vignali and Kuchroo 2012), whereas IL-35 is generally thought to be produced by regulatory $\mathrm{T}$ (Treg) and $\mathrm{B}$ cells, although they were recently detected in human tolerogenic DCs (Pylayeva-Gupta 2016). A unique feature of these cytokines is their heterodimeric subunit composition whereby the $\alpha$-subunit (p19, p28, p35) and $\beta$-subunit (p40, Ebi3) are differentially shared to generate IL-12 (p40-p35), IL23 (p40-p19), IL-27 (Ebi3-p28), and IL-35 (p40-p35) (Fig. 1A). Given their ability to share $\alpha$ - and $\beta$-subunits, it has been predicted that combinations such as Ebi3-p19 and p28-p40 could exist and serve physiological function (Fig. 1B) (Wang et al. 2012; Flores et al. 2015; Ramnath et al. 2015). Similarly, the subunitsharing feature of the IL-12 cytokine family also extends to its receptor chain usage (Fig. 1B). Although they share structural similarities and downstream signaling components, members of the IL-12 cytokine family mediate distinct biological functions. IL-12 and IL-23 are proinflammatory cytokines and are required for the development of Th1 and Th17 cells (Vignali and Kuchroo 2012). In contrast, IL-27 has im-

Editors: Warren J. Leonard and Robert D. Schreiber

Additional Perspectives on Cytokines available at www.cshperspectives.org

Copyright (C) 2018 Cold Spring Harbor Laboratory Press; all rights reserved; doi: 10.1101/cshperspect.a028530

Cite this article as Cold Spring Harb Perspect Biol 2018;10:a028530 
J. Yan et al.
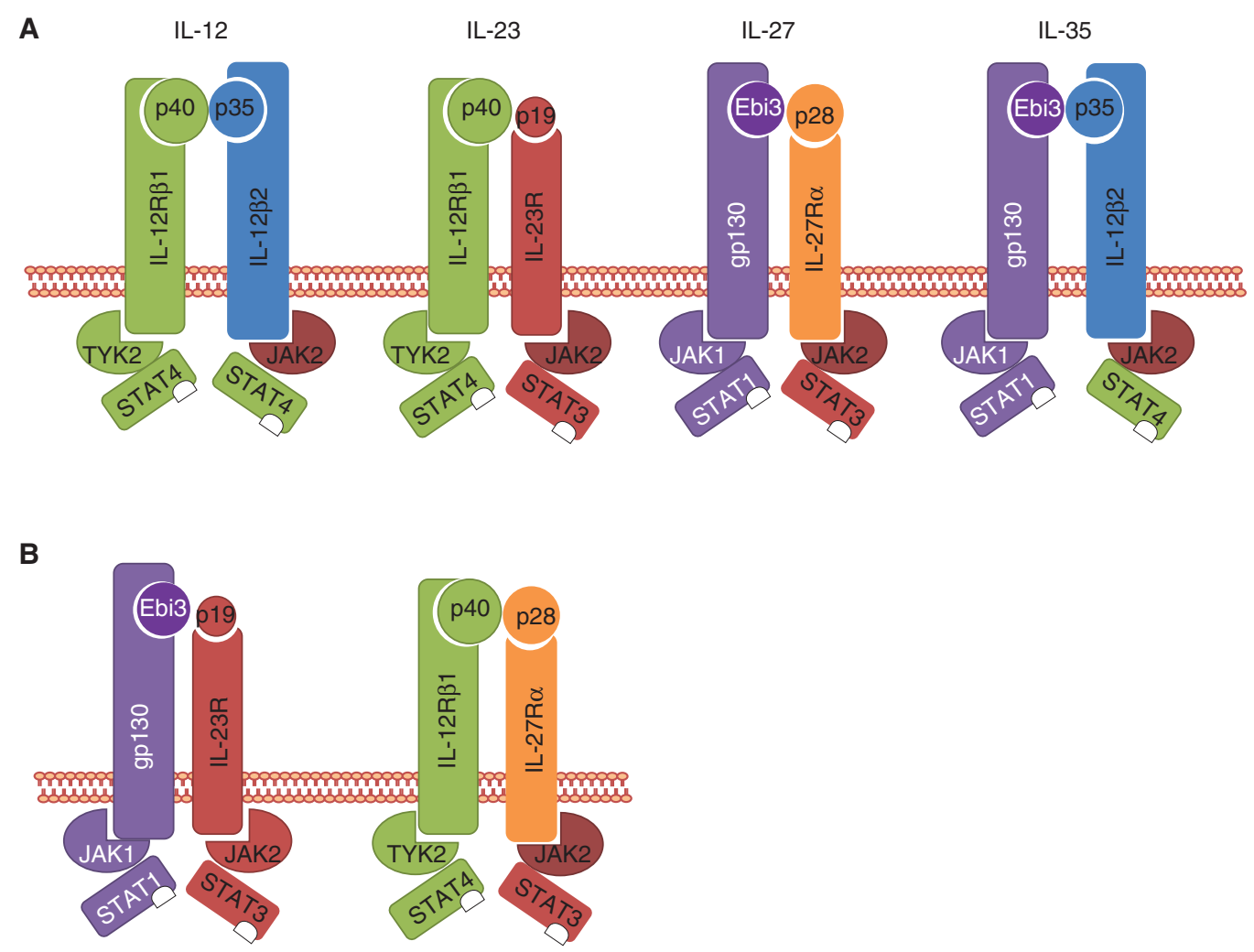

Figure 1. Schematic representation of the interleukin (IL)-12 cytokine family and their receptors, and associated Janus kinase and signal transducers and activators of transcription (JAK-STAT) signaling partners. (A) Current members of the IL-12 family with defined physiological function. (B) Potential new members of the IL-12 cytokine family that can be generated following subunit pairing. Ebi3, Epstein-Barr virus-induced gene 3 protein (also known as IL-27ß); IL-12R, IL-12 receptor; IL-23R, IL-23 receptor; TYK2, tyrosine kinase 2.

munosuppressive function and can curtail different classes of inflammation through its ability to directly modify $\mathrm{CD} 4^{+}$and $\mathrm{CD} 8^{+}$T-cell effector functions, to induce IL-10, and to promote specialized Treg cell responses (Yoshida and Hunter 2015). Likewise, IL-35 has an immunosuppressive function as shown by its ability to induce the development of IL-35-producing induced Tregs and the suppression of T-cell effector function and proliferative capacity in a variety of in vitro and in vivo systems (Vignali and Kuchroo 2012; Pylayeva-Gupta 2016).

In cancer, inflammation has been shown to play a critical role in tumor initiation, growth, and metastasis (Grivennikov et al. 2010; Elinav et al. 2013). It is now appreciated that the balance between the proinflammatory cytokine IL-12 and IL-23 in tumors can shape the development of antitumor or protumor immunity. Given that the importance of IL-12 in promoting antitumor immunity is well recognized and recently reviewed (Tugues et al. 2015), this review will particularly focus on discussing the role of IL23 in tumor biology and its mechanism of action in promoting tumor growth and metastases. Finally, we discuss how IL-12 and IL-23 are crossregulated and how the IL-12/IL-23 axis of inflammation can be targeted for cancer therapy.

\section{ROLE OF IL-12 AND IL-23 IN TUMOR BIOLOGY}

APCs, such as DCs and macrophages, are thought to be the predominant source of IL- 
12 and IL-23 (Hunter 2005). A major role of IL12 is to promote differentiation of Th1 cells and to induce type II interferon (IFN)- $\gamma$ production. The requirement for host IL-12 and its downstream cytokine in activating antitumor immunity is well recognized and has been previously reviewed extensively (Colombo and Trinchieri 2002; Dunn et al. 2006; Tugues et al. 2015). A number of studies have clearly illustrated the importance of endogenous IL-12 and IFN- $\gamma$ in preventing cancer initiation, growth, and metastasis. In contrast, IL-23 plays an important role in promoting the proliferation and effector function of Th17 cells, which are characterized by expression of the IL-17 family cytokines (Aggarwal et al. 2003; Langrish et al. 2004; Langrish et al. 2005). Mice that were deficient for IL-12/23p40 or IFN- $\gamma$ and challenged with methylcholanthrene-A (MCA), a chemical carcinogen, displayed increased rate and frequency of tumor growth compared to wild-type (WT) controls (Kaplan et al. 1998; Smyth et al. 2000). In contrast, mice deficient in IL-23p19 were strongly protected from developing MCA-induced fibrosarcomas (Teng et al. 2010). In another study, using a mouse model of dimethylbenz[a] anthracene (DMBA)-initiated and 12-O-tetradecanoylphorbol-13-acetate (TPA)-promoted two-stage skin carcinogenesis, IL-12/23p40-deficient and IL-23-p19-deficient mice displayed significantly decreased numbers of carcinogen-induced papillomas compared to WT mice, whereas the opposite was observed in IL-12p35-deficient mice (Langowski et al. 2006). Similarly, mice lacking IL-12p35 and IFN- $\gamma$ were more susceptible to mortality caused by $N$-methyl- $N$-nitrosourea (MNU)-induced lymphoma compared to IL-12/23p40deficient mice (Liu et al. 2004). Although naïve IL-12/23p40-deficient mice did not display any increase in tumor development compared to WT mice when monitored over their normal life span (Street et al. 2002), a proportion of aged mice deficient for IL-12R $\beta 2$ and, hence, nonresponsive to IL-12, developed plasmacytoma and lung epithelial tumors (Airoldi et al. 2005). In addition to directly activating T-cell and natural killer (NK) cell effector function, IL-12 and IFN- $\gamma$ can modulate the tumor mi- croenvironment to be more conducive to antitumor immunity by inhibiting angiogenesis and expanding intratumoral Tregs (Cao et al. 2009; Tugues et al. 2015). Nevertheless, IL-12 may have IFN- $\boldsymbol{\gamma}$-independent tumor-suppressive properties. A study using IL-12-producing B16 melanomas, in which innate lymphoid tissue-inducer cells but not $\mathrm{T}$ and NK cells induced tumor suppression (Eisenring et al. 2010), showed the pleiotropic ability of IL-12 to activate multiple arms of antitumor immunity.

The data that support the tumor-promoting effect of host IL-23 is also strong. A seminal paper by Langowski et al. (2006) provided the first demonstration that mice deficient in IL23 p19 were resistant to DMBA/TPA-induced skin papillomas and this resistance correlated with a significant increase in $\mathrm{CD}^{+} \mathrm{T}$ cells infiltrating the skin and a reduction in IL-17A, matrix metallopeptidase 9 (MMP9), CD31, granulocytes $\left(\mathrm{Gr}-1^{+}\right)$, and macrophages $\left(\mathrm{CD} 11 \mathrm{~b}^{+}\right.$, F4 $/ 80^{+}$). A study by Teng et al. (2010) further confirmed the resistance phenotype of these mice to DMBA/TPA-induced skin papillomas and also highlighted their resistance to MCAinduced fibrosarcomas. Interestingly, IL-17A did not promote the formation of MCA-induced fibrosarcomas, showing that IL-23p19 had tumor-promoting properties independent of IL-17A (Teng et al. 2010). In contrast to the MCA model, mice deficient for IL-12/IL-23p40 were still protected from tumor development following DMBA/TPA treatment, suggesting in this model that the loss of IL-23 was more important than the loss of IL-12 (Teng et al. 2010). In this model, Il17a-deficient mice displayed a protective phenotype albeit weaker than Il23a-deficient mice. Furthermore, this study also showed that, not only did IL-23 suppress the antitumor function of $\mathrm{T}$ cells as first uncovered by Langowski et al. 2006, it also suppressed the antimetastatic function of NK cells (Teng et al. 2010). In two other de novo mouse models of colon carcinogenesis (CPC-APC, $\mathrm{Apc}^{\mathrm{Min} /+}$ ), IL-23 and IL-17A both had tumorpromoting effects as loss of IL-23/IL-23R/ IL-17R or IL-23R/IL-17A blockade resulted in reduced tumor load (Wu et al. 2009; Grivennikov et al. 2012). Interestingly, one study re- 
J. Yan et al.

ported that expression of IL-23 alone in mice was sufficient to induce rapid $(3-4 \mathrm{wk})$ de novo development of intestinal adenomas with $100 \%$ incidence. Tumorigenesis was mediated by type 3 innate lymphoid cells (ILC3) but independent of exogenous carcinogens, Helicobacter colonization, or preexisting tumor-suppressor gene mutations (Chan et al. 2014). Similarly, a role for IL-23 has also been shown for the T-cell-mediated tumor dormancy phase (equilibrium) of cancer immunoediting (Schreiber et al. 2011), best characterized in the MCA-induced fibrosarcoma model (Koebel et al. 2007). In mice bearing dormant tumors induced by MCA, anti-IL-23 resulted in the elimination of the residual tumor cells, whereas anti-IL-12p40 (IL-12 and IL-23) led to their outgrowth (Teng et al. 2012), thus showing that loss of IL-23 was not sufficient to compensate for loss of IL-12 in this setting. Overall, these studies suggest the hierarchy of dominance between IL-12 in tumor suppression and IL-23 in tumor promotion in de novo models of inflammation-induced carcinogenesis varies, and this can be because of the type and location of the tumor and the immune cell infiltrates.

On the contrary, there have been a number of studies suggesting that IL-23 can have tumor suppressing effects when it is overexpressed in different tumor cell lines and implanted into mice (Lo et al. 2003; Chiyo et al. 2004; Hu et al. 2006, 2009; Oniki et al. 2006; Shan et al. 2006; Yuan et al. 2006; Kaiga et al. 2007; Reay et al. 2012; Ngiow et al. 2013). A recent study also showed that injection of IL-23 in combination with a transforming growth factor $\beta$ (TGF$\beta)$ receptor inhibitor could suppress the progression of premalignant lesions to cancer in a 4-nitroquinoline-1-oxide (4NQO) carcinogeninduced mouse model of oral cancer due to maintenance of Th17 cells and preventing their shift to a Treg phenotype (Young et al. 2016). In an acute UV-induced immunosuppression model, IL-23 was shown to be important in reducing UV-induced DNA damage and inhibiting UV-induced Tregs (Majewski et al. 2010). Similarly, a later study reported that mice deficient for IL-23p19 and chronically exposed to UVB were found to have a higher likelihood of developing tumors, particularly nonepithelial sarcomas, compared to the WT controls (Jantschitsch et al. 2012). One explanation could be that Th17 cells or IL-17A may have a role in tumor suppression similar to the DMBA/TPA model, although the role of Th17/IL-17A was not examined in this study. Although these data appear contradictory at first, the caveat of most of these experiments is that the expression of IL23 is in a nonphysiological manner.

\section{CLINICAL RELEVANCE OF IL-23 EXPRESSION IN HUMAN CANCERS}

In agreement with the role of endogenous IL-23 in promoting mouse tumor growth, IL-23 was found to be overexpressed in many human cancers (Table 1). Similarly, two functional genetic variants of the IL-23R (IL-23R rs $1884444 \mathrm{~T}>\mathrm{G}$ and rs6682925 T $>$ C) have been found to contribute to susceptibility to solid cancer and blood malignancies. However, the functional consequences of these variants in modulating IL-23R signaling are not clear (Chu et al. 2012; Qian et al. 2013a; Xu et al. 2013). In contrast, there has only been one clinical study in ovarian cancer in which a higher level of intratumoral IL-23p19 transcript correlated with improved patient overall survival. However, higher levels of intratumoral IL-12p35 transcripts were also measured in this study (Wolf et al. 2010). Overall, these studies provide compelling evidence that supports the involvement of IL-23 in the pathogenesis of different cancers, particularly those that are of inflammation-induced origin (Elinav et al. 2013).

\section{CELLULAR SOURCES OF IL-23 IN TUMORS}

In mice and humans, the main sources of IL-23 are thought to be produced by myeloid cells in response to exogenous or endogenous signals, such as damage-associated molecular patterns (DAMPs), pathogen-associated molecular patterns (PAMPs), or tumor-secreted factors such as prostaglandin E2 ( $\mathrm{PGE}_{2}$ ) (Qian et al. 2013b; von Scheidt et al. 2014; Chang et al. 2015; Teng et al. 2015; Kvedaraite et al. 2016). However, it remains unclear which myeloid subsets in tu- 


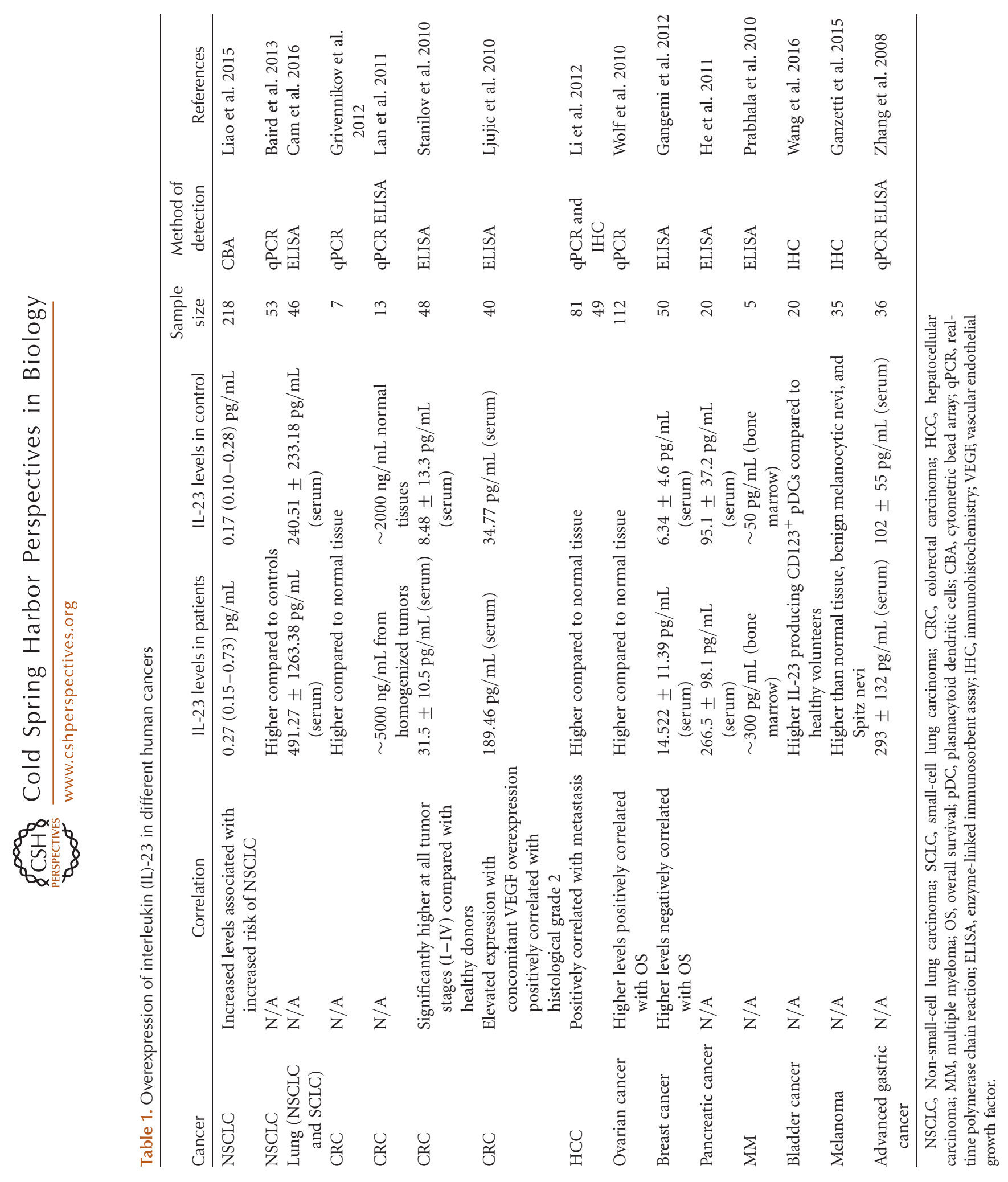


J. Yan et al.

mors secrete IL-23, and questions remain as to whether tumors themselves can also secrete IL23. In mice, most studies have quantified IL23p19 messenger RNA (mRNA) expression, given the lack of current reagents that can robustly detect IL-23 protein levels by ELISA or intracellular staining. However, a caveat is that increased expression of $\mathrm{p} 19$ mRNA may not correlate with the translation of $\mathrm{p} 19$ protein and/or formation of secreted bioactive IL-23, which requires coexpression and disulfide bond formation between the IL-23p19 and IL-12p40 subunits in the same cell (Waibler et al. 2007; Brentano et al. 2009; Floss et al. 2015). IL-23 has been measured in the supernatant from

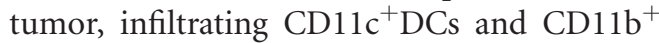
CD11 $\mathrm{c}^{-}$macrophages sorted from mice bearing subcutaneous B16 melanoma tumors (Kortylewski et al. 2009). In CPC-APC/IL-23-/mice harboring the green fluorescent protein (GFP) gene in the IL-23p19 locus, GFP was detected in both $\mathrm{CD}_{1} \mathrm{~b}^{+}$or $\mathrm{CD} 11 \mathrm{~b}^{-}$cells derived from the mesenteric lymph node or tumor, although this was not quantitated and control staining was not shown (Grivennikov et al. 2012). In B16F10 and RM-1 tumor-bearing lungs, expression of IL-23, as measured by flow cytometry, was found to be restricted to $\mathrm{MHC}-\mathrm{II}^{+} \mathrm{CD} 11 \mathrm{~b}^{+} \mathrm{CD} 11 \mathrm{c}^{+}$cells rather than $\mathrm{MHC}-\mathrm{II}^{+} \mathrm{CD} 11 \mathrm{c}^{+} \mathrm{CD} 11 \mathrm{~b}^{-}$cells, following lipo- polysaccharide (LPS) restimulation (von Scheidt et al. 2014). Overall, this indicates that mouse IL23 production can be restricted to specific immune cell subsets and depends on the context and environment in which it is measured.

To date, there have been no convincing studies showing that mouse tumor cells themselves produce IL-23. IL-23 (as measured by ELISA) was not detected in in vitro culture of various experimental mouse tumor cell lines such as EG7, B16F10, and RM-1 (von Scheidt et al. 2014). Similarly, in another study, very little IL-23 was detected in in vitro cultures of B16 and C4 melanoma tumor cell lines (Kortylewski et al. 2009). However, whether these cell lines can produce IL-23 following exposure to various metabolites or cytokine stimulation or following in vivo inoculation remains to be examined. Similarly, only a few studies have reported that human tumor cell lines themselves could secrete IL-23 (Table 2). However, these studies generally used real-time polymerase chain reaction (qPCR) and/or Western blotting to measure the presence of IL-23p19; whether bioactive IL-23 is secreted remains to be validated.

\section{EXPRESSION PATTERN OF IL-12R AND IL-23R}

The IL-12 and IL-23 receptors are made up of IL-12R $\beta 1$ and IL-12R $\beta 2$ or IL-12R $\beta 1$ and IL-

Table 2. Interleukin (IL)-23-producing human tumor cell lines

\begin{tabular}{|c|c|c|}
\hline Human tumor cell lines & $\begin{array}{l}\text { IL-23 detection } \\
\text { method }\end{array}$ & References \\
\hline $\begin{array}{l}\text { Human lung carcinoma cell lines } \\
\text { A549 (adenocarcinoma) } \\
\text { SK-MES-1 (squamous-cell carcinoma) } \\
\text { H1299, H460, and H647 (large-cell carcinoma) } \\
\text { BEAS2B (SV40 transformed normal bronchoepithelia) } \\
\text { HBEC3, HBEC4, and HBEC5 (normal bronchial epithelial } \\
\text { cell lines immortalized in the absence of viral oncoproteins) }\end{array}$ & RT-PCR & Baird et al. 2013 \\
\hline $\begin{array}{l}\text { Human oral squamous cell carcinoma } \\
\text { HSC-2, HSC-3, HSC- } 4 \text {, and Ca9-22 }\end{array}$ & $\mathrm{qPCR}$ & Fukuda et al. 2010a,b \\
\hline $\begin{array}{l}\text { Human hepatocellular carcinoma } \\
\text { HepG2, PLC8024, QGY7703, H2P, H2M, Huh7, and MHCC-97L }\end{array}$ & WB & Li et al. 2012 \\
\hline $\begin{array}{l}\text { Human pancreatic carcinoma cell line } \\
\text { PANC-1 }\end{array}$ & $\begin{array}{l}\text { qPCR, cytokine } \\
\text { array }\end{array}$ & Chang et al. 2015 \\
\hline
\end{tabular}


23R, respectively (Fig. 1A). Signaling by IL-12 stimulates nonreceptor Janus kinase 2 (JAK2) and tyrosine kinase 2 (TYK2) activity resulting in the phosphorylation of signal transducers and activators of transcription (STAT) family members, particularly STAT4 (Zundler and Neurath 2015), whereas STAT3 is preferentially activated following IL-23 stimulation (Floss et al. 2015). In mice and humans, a range of innate and adaptive immune cells have been shown to express IL-12 and IL-23 receptors constitutively as measured by qPCR, flow cytometry, or using an IL-23R GFP KI reporter mouse (Tables 3 and 4), although they appear to be expressed at varying levels, which can be further up-regulated following activation (Ivanov et al. 2006; Ghoreschi et al. 2010; Gaffen et al. 2014). In addition, it was suggested that the IL-12 and IL-23 receptors may not be expressed on the same cell population (Chognard et al. 2014). Therefore, it will be interesting to assess the IL-23R-expressing cells present in tumors and whether their composition differs in different tumor microenvironments. Although mouse tumor cell lines generally have not been reported to express IL-23R, a number of studies have reported that some human tumor cells lines expressed IL-23R and could respond to IL-23 (Table 5). Interestingly, varying levels of IL-23R (as measured by flow cytometry) were also detected on primary tumors, such as pediatric B-ALL cell samples compared to their normal counterparts (Cocco et al. 2010) in diffuse large B-cell lymphoma (DLBCL) and follicular lymphoma (FL) (Cocco et al. 2012) and in a proportion of colorectal carcinoma (CRC) (Suzuki et al. 2012).

\section{MECHANISM OF IL-23 IN PROMOTING TUMOR GROWTH AND METASTASES}

The antitumor and antimetastatic activities of IL-12 are thought to be mediated by STAT4 activation of IFN- $\gamma$ (Colombo and Trinchieri 2002; Trinchieri 2003; Zundler and Neurath 2015). In contrast, the mechanism of action of IL-23 is not fully elucidated. Although IL-23 has been linked with Th17 cells and is crucial for their function and cytokine production (such as IL-17A) in vivo (Muranski and Restifo
2013), IL-23 can have tumor-promoting function independent of IL-17A (as discussed above). Interestingly, a recent study reported that mice lacking IL-17A had reduced lung metastases (Kulig et al. 2016), although mice lacking IL-23 were not examined in the same assay. Nevertheless, it is likely that IL-17A will be involved in the protumor activity of IL-23 because, in some models, anti-IL-17A alone or in combination with anti-IL-23R could reduce bacterial-induced colon carcinogenesis ( $\mathrm{Wu}$ et al. 2009). Similarly, in a mouse model of Apc-driven colorectal cancer model, IL-23 signaling was shown to promote tumor growth and progression and development of an intratumoral IL-17 response (Grivennikov et al. 2012). However, Th17 cells and IL-17A have also been reported to have tumor-suppressing function in some mouse models of cancer and in certain human cancers (Zou and Restifo 2010; Wilke et al. $2011 b$ ). It would appear that the requirement of IL-17 for the tumor-promoting activity of IL-23 may be tumor-dependent. In one study, it was reported that tumor-infiltrating Tregs expressed IL-23R and that blocking IL-23R signaling could reduce Treg numbers and their capacity to secrete IL-10 in a number of experimental mouse tumor models (Kortylewski et al. 2009). However, expression of IL-23R on Tregs has not been reported elsewhere. Nevertheless, this study also showed that STAT3 enhanced the expression of IL-23 in macrophages but inhibited IL-12 in DCs in the tumor microenvironment (Kortylewski et al. 2009). Thus, one mechanism by which IL-23 promotes tumorigenesis may be through driving protumor inflammation to suppress antitumor effector cells.

In addition to IL-17A and IL-10, other Th17 cytokines that have been reported to be regulated by IL-23, including other IL-17 isoforms and IL-22 (Eyerich et al. 2010; Cornelissen et al. 2011). Similar to IL-17A, IL-22 has been shown in different mouse models of inflammation/ carcinogen-induced cancer to mediate both tumor-promoting and -suppressing functions (Blake and Teng 2014). Importantly, it is clear that the function of Th17 cells in tumor immunity cannot be linked just to the function of the IL-17A given that other cells of the innate and 
J. Yan et al.

Table 3. IL-23R expression on immune cells in mice

\begin{tabular}{|c|c|c|c|c|}
\hline Immune cells & Organ & Mouse & Methods & References \\
\hline$\gamma \delta \mathrm{T}\left(\gamma \delta^{+}\right)$ & Spleen, LP & Naïve IL-23R GFP B6 & $\mathrm{qPCR}, \mathrm{FC}$ & Chognard et al. 2014 \\
\hline$\gamma \delta \mathrm{T}\left(\gamma \delta^{+}\right)$ & Lung & Naïve IL-23R GFP B6 & $\mathrm{FC}$ & Paget et al. 2015 \\
\hline$\gamma \delta \mathrm{T}\left(\gamma \delta^{+}\right)$in vitro cultured & Spleen & Naïve B6 & $\mathrm{qPCR}, \mathrm{FC}$ & Sutton et al. 2009 \\
\hline$\gamma \delta \mathrm{T}\left(\gamma \delta^{+}\right)$ & LN, LP & Naïve IL-23R GFP B6 & FC & Awasthi et al. 2009 \\
\hline$\gamma \delta \mathrm{T}\left(\mathrm{CD}^{+} \mathrm{TCR}^{+}\right)$ & Spleen, LN & EAE B6 mice & $\mathrm{qPCR}, \mathrm{FC}$ & Raverdeau et al. 2016 \\
\hline $\begin{array}{l}\text { Memory T cells }\left(\mathrm{DX}^{-}\right. \\
\left.\mathrm{TCR}^{+} \mathrm{CD}^{+} \mathrm{L}^{-}\right)\end{array}$ & Spleen & Naïve B6 & $\mathrm{qPCR}$ & Rachitskaya et al. 2008 \\
\hline $\mathrm{CD}^{+}{ }^{+} \mathrm{T}$ cells $\left(\mathrm{CD}^{+}{ }^{+} \mathrm{CD} 4^{+}\right)$ & LP & Naïve IL-23R GFP B6 & FC & Chan et al. 2014 \\
\hline $\mathrm{CD}^{+}{ }^{+} \mathrm{T}\left(\mathrm{CD} 4^{+} \mathrm{TCR}^{+}\right)$ & Spleen, LN & Naïve IL-23R GFP B6 & FC & $\begin{array}{l}\text { Awasthi et al. 2009; } \\
\quad \text { Chognard et al. } 2014\end{array}$ \\
\hline $\begin{array}{l}\text { Th17 cells }\left(\mathrm{CD}^{+}\right) \text {cultured in } \\
\text { in vitro Th17 conditions }\end{array}$ & Spleen & Naïve B6 & qPCR & $\begin{array}{l}\text { Ciric et al. 2009; El-Behi } \\
\quad \text { et al. } 2011\end{array}$ \\
\hline LTi cells $\left(\mathrm{CD}^{-} \mathrm{CD}^{+}\right)$ & LP & Naïve IL-23R GFP B6 & FC & Awasthi et al. 2009 \\
\hline Treg $\left(\mathrm{CD}^{+} \mathrm{FOXP}^{+}\right)$ & $\begin{array}{r}\text { Tumor, } \\
\text { DLN }\end{array}$ & $\begin{array}{l}\text { B16, MC38 and MB49 } \\
\text { tumor-bearing B6 }\end{array}$ & FC & Kortylewski et al. 2009 \\
\hline $\begin{array}{l}\text { Tc17 }\left(\mathrm{CD}^{+}\right) \text {Cultured in } \\
\text { in vitro Tc17 conditions }\end{array}$ & Spleen & Naïve B6 & qPCR & Ciric et al. 2009 \\
\hline $\mathrm{B}$ cells $\left(\mathrm{CD} 19^{+} \mathrm{B}^{2} 20^{+}\right)$ & Spleen, LP & Naïve IL-23R GFP B6 & FC & Chognard et al. 2014 \\
\hline $\operatorname{NKT}\left(\mathrm{DX}^{+}{ }^{-} \mathrm{TCR}^{+}{ }^{+}\right)$ & Spleen & Naïve B6 & $\mathrm{qPCR}$ & Rachitskaya et al. 2008 \\
\hline $\begin{array}{l}\text { NKT }(\alpha-\mathrm{GC} / \mathrm{CD} 1 \mathrm{~d} \text { tetramer } \\
\left.\mathrm{TCR}^{+}{ }^{+} \mathrm{NK} 1.1^{-}\right) \\
\text {stimulated with anti-CD3 } \\
\text { and anti-CD28 }\end{array}$ & Thymus & Naïve B6 & qPCR & Coquet et al. 2008 \\
\hline $\mathrm{DC}\left(\mathrm{CD} 11 \mathrm{c}^{+}\right)$ & Spleen, LN & $\begin{array}{l}\text { Naïve B6, naïve IL-23R } \\
\text { GFP B6 }\end{array}$ & qPCR, FC & $\begin{array}{l}\text { Awasthi et al. 2009, El- } \\
\text { Behi et al. } 2011\end{array}$ \\
\hline Macrophage $\left(\mathrm{CD} 11 \mathrm{~b}^{+}\right)$ & LN, LP & Naïve IL-23R GFP B6 & FC & Awasthi et al. 2009 \\
\hline $\begin{array}{l}\text { Inflammatory macrophage } \\
\qquad\left(\mathrm{CD}^{-}{ }^{-} \mathrm{CD}_{\left.11 \mathrm{~b}^{+} \mathrm{CD} 45^{+}\right)}\right.\end{array}$ & CNS & EAE B6 & $\mathrm{qPCR}$ & Cua et al. 2003 \\
\hline $\begin{array}{l}\text { Neutrophil thioglycollate } \\
\text { induced }\end{array}$ & $\begin{array}{l}\text { Peritoneal } \\
\text { cavity }\end{array}$ & Naïve B6 & $\mathrm{qPCR}$ & Chen et al. 2016 \\
\hline Neutrophil $\left(\right.$ Ly6G $\left.^{+}\right)$ & $\mathrm{BM}$ & Naïve B6 & qPCR, FC & Taylor et al. 2014 \\
\hline Neutrophils (stimulated) & Colon & DSS-treated B6 & $\mathrm{qPCR}$ & Zindl et al. 2013 \\
\hline $\mathrm{LT} \mathrm{R}^{+}$cells & LP & DSS-treated mice & $\mathrm{qPCR}$ & $\begin{array}{l}\text { Macho-Fernandez et al. } \\
2015\end{array}$ \\
\hline $\begin{array}{l}\text { ILC3 (NKp46 }{ }^{+} \mathrm{CD}_{127^{+}} \\
\left.\text {CD117 }{ }^{+} \mathrm{CD}_{49 \mathrm{~b}^{-}}\right)\end{array}$ & Spleen & Naïve IL-23R GFP B6 & FC & Chognard et al. 2014 \\
\hline 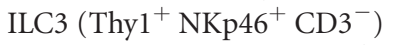 & LP & Naïve IL-23R GFP mice & FC & Chan et al. 2014 \\
\hline $\begin{array}{l}\text { LTi-like cells }\left(\mathrm{CD}^{-} \mathrm{CD}^{-} 2^{+}\right. \\
\left.\mathrm{CD}^{+} 17^{+}\right)\end{array}$ & Spleen & Naïve IL-23R GFP mice & $\mathrm{FC}$ & Chognard et al. 2014 \\
\hline $\begin{array}{l}\text { LTi }\left(\text { Thyl } 1^{+} \text {cKIT }^{+} \mathrm{NKp}^{-} 6^{-}\right. \\
\left.\mathrm{CD}^{-}{ }^{-}\right)\end{array}$ & LP & Naïve IL-23R GFP mice & FC & Chan et al. 2014 \\
\hline Thymocytes $\left(\right.$ Thy $1.2^{+}$) & Thymus & Naïve B6 & $\mathrm{qPCR}, \mathrm{FC}$ & Li et al. 2014 \\
\hline Thymic epithelial cells & Thymus & Naïve B6 & $\mathrm{qPCR}$ & Li et al. 2014 \\
\hline
\end{tabular}

FC, Flow cytometry; DLN, draining lymph node; LN, lymph node; LP, lamina propria; EAE, experimental autoimmune encephalomyelitis; B6, C57BL/6 mice; Treg, Tregulatory cell; LTi, lymphoid tissue inducer cell; CNS, central nervous system; DSS, dextran sodium sulfate; LT $\beta R$, lymphotoxin $\beta$ receptor; ILC3, type 3 innate lymphoid cells; BM, bone marrow; NKT, natural killer T cell; DC, dendritic cell; GFP, green fluorescent protein; IL, interleukin; qPCR, real-time polymerase chain reaction. 
Roles of IL-12 and IL-23 in Cancer

Table 4. Interleukin (IL)-23R expression on human immune cells

\begin{tabular}{|c|c|c|c|}
\hline Immune cells & $\begin{array}{l}\text { Organ cells were } \\
\text { isolated from }\end{array}$ & $\begin{array}{l}\text { Method of } \\
\text { detection }\end{array}$ & References \\
\hline$\gamma \delta \mathrm{T}$ cells $\left(\mathrm{CD}^{+}{ }^{+} \mathrm{TCR}^{+}\right)$ & PBMC & RT-PCR & Chognard et al. 2014 \\
\hline$\gamma \delta \mathrm{T}$ cells $\left(\mathrm{CD}^{+}{ }^{+} \gamma \gamma 9^{+}\right)$ & PBMC, cord blood & FC & Moens et al. 2011 \\
\hline $\mathrm{CD}^{+}{ }^{+} \mathrm{T}$ cells $\left(\mathrm{CD} 3^{+} \mathrm{CD}^{+}\right)$ & PBMC & RT-PCR & Chognard et al. 2014 \\
\hline $\mathrm{CD}^{+}{ }^{+}$memory $\mathrm{T}$ cells $\left(\mathrm{CD} 4^{+} \mathrm{CD} 45 \mathrm{RO}^{+}\right)$ & PBMC & FC & Sarin et al. 2011 \\
\hline Memory T cells $\left(\mathrm{DX}^{-} \mathrm{TCR}^{+} \mathrm{CD}^{-} \mathrm{L}^{-}\right)$ & PBMC & qPCR & Rachitskaya et al. 2008 \\
\hline Tc17 cells $\left(\mathrm{CD}^{+}\right)$ & PBMC & FC & Sarin et al. 2011 \\
\hline $\mathrm{CD}^{+}{ }^{+} \mathrm{T}$ cells $\left(\mathrm{CD}^{+}{ }^{+} \mathrm{CD}^{+}{ }^{+}\right)$ & PBMC & RT-PCR & Chognard et al. 2014 \\
\hline 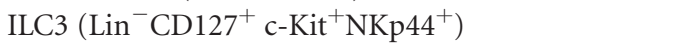 & Tonsil & qPCR & Bernink et al. 2013 \\
\hline Neutrophil & PBMC & IF & Taylor et al. 2014 \\
\hline NKT cells $\left(\mathrm{DX} 5^{+} \mathrm{TCR}^{+}{ }^{+}\right)$ & PBMC & qPCR & Rachitskaya et al. 2008 \\
\hline MAIT cells $\left(\mathrm{CD}^{+}{ }^{+} \mathrm{CD} 161^{\text {high }} \mathrm{V} \alpha 7.2^{+} \mathrm{CD} 4^{-} \mathrm{TCR} \gamma \delta^{-}\right)$ & Liver blood & \multicolumn{2}{|c|}{ Nanostring Tang et al. 2013} \\
\hline
\end{tabular}

PBMC, Peripheral blood mononuclear cells; MAIT, mucosal-associated invariant T cells; ILC3, type 3 innate lymphoid cells; FC, flow cytometry; IF, immunofluorescence; RT-PCR, reverse transcription polymerase chain reaction; qPCR, real-time polymerase chain reaction; NKT, natural killer T cell.

adaptive immune system, such as $\gamma \delta \mathrm{T}$ cells, NK-T cells, and ILCs, also produce substantial quantities of this and other cytokines such as IL-22 (Wilke et al. 2011a,b; Sabat et al. 2013). Other cytokines, including IL-6 and granulocyte macrophage colony-stimulating factor (GM-CSF), can also be induced downstream from IL-23/IL-23R signaling and have also been implicated in the pathogenesis of several autoinflammatory and autoimmune diseases (Yen et al. 2006; Lindroos et al. 2011; Wu et al. 2016). Whether these cytokines contribute to the protumor effect of IL-23 remains to be investigated. IL-23 is also thought to negatively regulate the functions and infiltration of $\mathrm{CD}^{+} \mathrm{T}$ cells into tumor tissue. IL-23p19-deficiency or anti-IL-23p19 antibody treatment has been shown to increase $\mathrm{CD} 8^{+} \mathrm{T}$-cell infiltration into DMBA/TPA-treated skin (Langowski et al. 2006), as measured by immunohistochemistry (IHC). Indeed, cytotoxic markers such as FasL, perforin, and granzymes were shown to be upregulated in carcinogen-treated skin of IL23p19-deficient mice (Langowski et al. 2006). Importantly, within tumors, $\mathrm{CD} 8^{+} \mathrm{T}$ cells have been shown to be required for tumor suppression mediated by ablation of IL-23/IL-23R signaling (Langowski et al. 2006; Teng et al. 2011; von Scheidt et al. 2014). However, so far, there is no clear evidence that IL-23R is expressed by tumor-infiltrating $\mathrm{CD}^{+} \mathrm{T}$ cells, and it is most likely that IL-23 suppresses the antitumor activity of $\mathrm{CD}^{+} \mathrm{T}$ cells indirectly. In addition to their effects on immune cells, IL-23R expression on human tumor cell lines has been reported. Coculture with IL-23 generally promoted their proliferation except in the case of B-cell malignancies in which a high dose of IL-23 was used (Table 5). Interestingly, it has also been shown that different concentrations of IL-23 can exert opposite effects on the capability of IL-23R expressing human lung cancer cells to proliferate (Li et al. 2013).

A key function of IL-23 appears to be its ability to promote tumor metastases through up-regulation of proangiogenic factors. Evidence suggests that IL-23 overexpression can induce metastasis of hepatocellular carcinoma (HCC), CRC, melanoma, and esophageal and thyroid cancer (Li et al. 2012; Suzuki et al. 2012; Zhang et al. 2014; Chen et al. 2015; Ganzetti et al. 2015; Klein et al. 2015; Mei et al. 2015). IL-23 was reported to directly up-regulate expression of MMP9 and vascular endothelial growth factor (VEGF)-C in human esophageal cancer cell lines to facilitate epithelial-mesenchymal transition and migratory ability in vitro (Chen et al. 2015). In the same study, patients with esophageal cancer $(n=23)$ who had lymphatic and distant metastasis compared to those who did not had significantly higher IL-23p19 expression (although the source of the anti-IL- 
J. Yan et al.

Table 5. Interleukin (IL)-23R expressing human tumor cell lines

\begin{tabular}{|c|c|c|c|}
\hline $\begin{array}{l}\text { Human tumor cell lines } \\
\text { expressing IL-23R }\end{array}$ & $\begin{array}{l}\text { IL-23R } \\
\text { detection } \\
\text { method }\end{array}$ & Effect of coculture with IL-23 & References \\
\hline $\begin{array}{l}\text { Lung adenocarcinoma: A549, } \\
\text { SPCA-1 }\end{array}$ & $\begin{array}{l}\text { IHC, IF } \\
\text { WB }\end{array}$ & $\begin{array}{l}\text { Low concentration promoted } \\
\text { proliferation, whereas high } \\
\text { concentration suppressed proliferation }\end{array}$ & $\begin{array}{l}\text { Li et al. } 2013 \\
\text { Baird et al. } 2013\end{array}$ \\
\hline $\begin{array}{l}\text { Oral squamous cell carcinoma: } \\
\text { HSC-2, HSC-3, HSC-4, Ca9- } \\
22\end{array}$ & WB, RT-PCR & Promoted proliferation of HSC-3 & $\begin{array}{l}\text { Fukuda et al. } \\
\text { 2010b }\end{array}$ \\
\hline $\begin{array}{l}\text { Pro-B-ALL cell line: RS4;11 } \\
\text { Pre-B-ALL cell line: } \\
\quad \text { Nalm-6, Nalm-697 }\end{array}$ & FC & $\begin{array}{l}\text { High concentration suppressed } \\
\text { proliferation and promoted apoptosis }\end{array}$ & Cocco et al. 2010 \\
\hline $\begin{array}{l}\text { B-cell lymphoma: SU-DHL-4, } \\
\text { DOHH-2, OCI-LY8 cell }\end{array}$ & FC & Suppressed proliferation of SU-DHL-4 & Cocco et al. 2012 \\
\hline Colon carcinoma: SW480 & RT-PCR, IHC & Not performed & Lan et al. 2011 \\
\hline $\begin{array}{l}\text { Colon carcinoma: SW480, } \\
\text { HCT116, and HT29 }\end{array}$ & ND & $\begin{array}{l}\text { Promoted proliferation of HCT116, HT29, } \\
\text { but not SW480 }\end{array}$ & $\begin{array}{l}\text { Shapiro et al. } \\
2016\end{array}$ \\
\hline $\begin{array}{l}\text { Colon carcinoma: MIP101, } \\
\text { DLD-1, and KM12c }\end{array}$ & WB & $\begin{array}{l}\text { Promoted proliferation and invasive } \\
\text { capability of DLD-1 only }\end{array}$ & $\begin{array}{l}\text { Suzuki et al. } \\
2012\end{array}$ \\
\hline $\begin{array}{l}\text { Hepatocellular carcinoma: } \\
\text { PLC8024 and QGY-7703 }\end{array}$ & ND & $\begin{array}{l}\text { Promoted invasion and migration and } \\
\text { production of MMP9 }\end{array}$ & Li et al. 2012 \\
\hline
\end{tabular}

WB, Western blot; IHC, immunohistochemistry; RT-PCR, reverse transcription polymerase chain reaction; MMP9, matrix metallopeptidase 9; FC, flow cytometry; IF; immunofluorescence; ND, not detected; B-ALL, B-acute lymphoblastic leukemia.

23 antibody used for IHC was not listed [Chen et al. 2015]). Similarly, another study also showed that IL-23 could promote the migration and invasive ability of HCC cell lines through up-regulation of MMP9 expression via activation of NF-кB/p65 (Li et al. 2012). Higher IL23p19 levels, as measured by mRNA expression and IHC, were also detected in primary HCC tumor tissues with metastasis compared with paired nontumor tissue (Li et al. 2012). IL-23 was also reported to correlate with IL-17A and MMP9 expression in these clinical samples. Similar findings were also reported for IL-23 in facilitating the migration and invasive ability of human thyroid cancer cell lines to migrate and this was mediated via an miR-25/SOCS4 signaling pathway (Mei et al. 2015). Additionally, higher IL-23p19 mRNA expression was present in thyroid cancer patients who had lymphatic and distant metastasis. It was also reported that IL-23 promoted the metastasis of CRC with impaired SOCS3 expression via a STAT5 pathway (Zhang et al. 2014). In melano$\mathrm{ma}$, astrocytes (glial cells) were reported to fa- cilitate human melanoma brain metastasis via secretion of IL-23 in an orthotopic brain melanoma metastases mouse model (Klein et al. 2015). Using IHC, Ganzetti et al. (2015) found that the intensity and percentage of IL-17 and IL-23 was significantly higher in malignant melanomas than in benign melanocytic or Spitz nevi. Overall, it appears that the direct effects of IL-23 are most likely mediated through induction of cell-cycle pathways (cyclin-dependent kinases and cyclin D) and oncogenic and associated genes that regulate growth-factor-induced signaling (AKT, NF-кB, AP-1) (Kortylewski et al. 2009; Chan et al. 2014).

\section{CROSS-REGULATION OF IL-12 AND IL-23}

In tumors, the ratio of IL-12 and IL-23 produced by DCs and macrophages will be determined by the balance of endogenous Toll-like receptor (TLR) agonists, danger signals, and/or tumor-derived mediators in the tumor microenvironment, leading to activation of their respective downstream pathways, which ulti- 
mately dictate tumor growth outcome (Gerosa et al. 2008; Ngiow et al. 2013). The mechanism by which IL-12 and IL-23 regulate each other is not well elucidated and may be quite complex. Some studies have reported that IFN- $\gamma$ can negatively regulate IL-23 production by inhibiting mouse Il23a gene-promoter activity (Sheikh et al. 2010, 2011). Conversely, another study showed that IL-23 antagonized IL-12-induced secretion of IFN- $\gamma$ (Sieve et al. 2010). Adding to the complexity, a recent study in mice suggested signaling through IL-23R may potentially promote IL-12 production, whereas signaling through IL-12R $\beta 2$ suppresses IL-1 $\beta$ and IL-23 (Chognard et al. 2014). Furthermore, a dichotomous pattern of expression for IL-12 and IL-23 receptors in both mouse and humans was reported in this study, suggesting that immune cells involved in antitumor responses may be quite distinct from those that are tumor promoting. Finally, IL-12 and IL-23 can also be regulated both genetically and epigenetically. It was reported that conventional DCs (cDCs) and plasmacytoid DCs ( $\mathrm{pDCs}$ ) from $\mathrm{Grm} 4^{-/-}$ mice produced higher amounts of IL-6 and IL-23, but less IL-12 and IL-27 compared to their WT counterparts in response to LPS or CpG-ODN, respectively (Fallarino et al. 2010). In addition, phosphatase $2 \mathrm{~A}$ has been shown to negatively regulate IL-23 but not IL-12 in LPS stimulated DC by suppressing IL-23p19 gene expression (Chang et al. 2010). In contrast, Trabid, a deubiquitinase, was reported to mediate epigenetic regulation of both $\mathrm{Il12}$ and Il23 gene expression (Balhara et al. 2016), while deubiquitinases ADAM10 and ADAM17 have been reported to mediate IL-23R ectodomain shedding (Franke et al. 2016). In mice and humans, differential splicing of the $I L-23 R$ gene has also been reported to generate antagonistic soluble IL-23R variants (Zhang et al. 2006; Kan et al. 2008; Mancini et al. 2008; Floss et al. 2015). These soluble IL-23R may potentially reduce the cellular responsiveness of IL-23R expressing cells toward IL-23 and can also bind to IL-23 and act as competitive antagonist of IL-23 signaling (Franke et al. 2016).

Recently, it was reported that IL-4 had opposing effects on the production of either IL-12 or IL-23 in which it promoted the IL-12-producing capacity of DCs while abrogating IL-23 production (Guenova et al. 2015). It is also possible that the IL-12 and IL-23 pathways can be regulated by their shared IL-12p40, p35, p19 subunits, and corresponding receptors. Free IL-12p40 exists in either homodimeric IL$12 \mathrm{p} 80$ or monomeric IL-12p40 forms in mice and human, and can act as natural antagonists of IL-12 and IL-23 by competing for binding to IL-12Rß1 (Mattner et al. 1993; Gillessen et al. 1995; Ling et al. 1995; Trinchieri 2003; Shimozato et al. 2006). Similarly, in mice, it has been reported that IL-12p80 suppressed splenic Tregs via induction of nitric oxide from APCs, and this suppression was dependent on IL$12 \mathrm{R} \beta 1$ rather than IL-12R $\beta 2$ in vitro (Brahmachari and Pahan 2009). Given that IL-12p35 is also used as a shared subunit by the inhibitory cytokine IL-35 (IL-12p35/Ebi3 [IL27p28]) produced by Tregs and B cells (Collison et al. 2007; Shen et al. 2014), one must also consider how the balance between IL-12 and IL-35 impacts on tumorigenesis (Banchereau et al. 2012). Similarly, a recent study showing that IL-23p19 can interact with Ebi3 (Ramnath et al. 2015) raises new questions regarding its physiological function and how it may regulate the other IL-12 family cytokines in which common subunits are shared.

Interestingly, a number of papers have also reported that immune checkpoint receptors such as TIM-3 and PD-1 expressed on monocytes/macrophages can regulate the balance of IL-12/IL-23 in viral infections such as hepatitis C (Zhang et al. 2011a,b; Wang et al. 2013). Similarly, a recent study reported that agonistic anti-BTLA inhibited DC-induced Th17- and Th1-cell responses because of decreased production of the Th17- and Th1-related cytokines IL-1 $\beta$, IL-6, IL-23, and IL-12p70 and reduced CD40 expression in DCs (Ye et al. 2016). Given that checkpoint receptors are a major pathway of tumor-induced immune suppression (Pardoll 2012), this represents another mechanism by which the IL-12/IL-23 balance can be affected. Overall, the subunit sharing between the IL-12 family of cytokines makes it difficult to definitively delineate the 
J. Yan et al.

function of each cytokine. Generating antibodies that can specifically neutralize the specific cytokine rather than the shared subunits might be a better approach for dissecting out the endogenous role these family members play in promoting or suppressing tumorigenesis.

\section{TARGETING THE IL-12/IL-23 AXIS OF INFLAMMATION FOR CANCER THERAPY}

It is now recognized that the immune system is actively suppressed in the tumor microenvironment and that lymphoid, myeloid, and granulocytic cells contribute to this suppression. In the past 5 years, therapies targeting T-cell immune checkpoint receptors have achieved remarkable success in the clinic, particularly in combination, and will increasingly become incorporated into standard-of-care for many cancer types (Smyth et al. 2016). Nevertheless, not all cancer types respond to checkpoint blockade even when targeted in combination. Given that human tumors are extremely heterogeneous with respect to their proportions of immune cells, blocking immunosuppressive pathways mediated by both $\mathrm{T}$ and myeloid cells may be required in certain cancer types to release full endogenous antitumor immunity.

A number of preclinical mouse studies have shown that changing the balance of IL-12 and IL-23 can promote tumor progression or suppression and thus targeting this axis may be beneficial particularly in combination immunotherapies. In one study, intratumoral IL-12 application in combination with systemic checkpoint blockade of CTLA-4 resulted in eradication of mice with orthotopic gliomas (Vom Berg et al. 2013). Similarly, another study showed a combination of agonistic anti-CD40 monoclonal antibodies (mAbs) to drive IL-12 production and anti-IL-23 mAbs to counter the tumor-promoting effects of IL-23 had greater antitumor activity than either agent alone (von Scheidt et al. 2014). The efficacy of this combination may potentially be effective in patients whose cancer display rich myeloid infiltrates and up-regulated IL-23 (e.g., sarcomas), where neutralization of IL-23 in the tumor microenvironment may allow the agonistic activity of anti-CD40 to be fully maximized. More recently, agonistic CD40 mAbdriven IL-12 was shown to reverse resistance to anti-PD-1 therapy in T-cell-rich tumors (Ngiow et al. 2016). Similarly, in a preclinical murine model of bladder cancer, Tasquiminod, a small molecule that binds S100A9 increased tumor mRNA expression levels of Il12b, Tbet, and Ifng and synergized with anti-PD-L1 to suppress tumor growth (Nakhle et al. 2016).

Prophylactic neutralization of IL-23 has been shown to significantly suppress experimental lung metastases of B16F10 melanoma, RM-1 prostate carcinoma, and 3LL lung carcinoma, which are controlled by host NK cells rather than $\mathrm{CD}^{+} \mathrm{T}$ cells (Teng et al. 2010, 2011). In mice bearing established lung metastases, IL-2 immunotherapy was enhanced in mice deficient for IL-23p19, suggesting neutralizing anti-IL-23 $\mathrm{mAbs}$ may synergize with immunotherapies that activate NK cells such as IL-2 (Teng et al. 2010). Neutralization of IL-23 also synergized with anti-ERBB2 $\mathrm{mAb}$ in suppressing subcutaneous growth of established Her-2/neu-positive breast tumors in mice (Teng et al. 2010). In addition, targeting of activating receptors such as CD137 or CD226 (DNAM-1) (Kohrt et al. 2012; Blake et al. 2016) or inhibitory receptors such as CD96 and TIGIT may also synergize with IL23 neutralization to suppress metastases (Blake et al. 2016). Alternatively, anti-IL-23p19 mAbs can be combined with chemotherapy, such as gemcitabine, that has been shown to induce IL-23p19 and IL-23R mRNA expression in non-small-cell lung carcinoma (NSCLC) cell lines (Baird et al. 2013).

\section{CONCLUSIONS}

In this review, we have discussed how the balance of proinflammatory cytokines IL-12 and IL-23 plays a key role in shaping the development of antitumor or protumor immunity, respectively. Although the antitumor efficacy of IL-12 is generally mediated via downstream activation of IFN- $\gamma$, IL-23 can have a tumor-promoting function independent of IL-17A, such as directly up-regulating proangiogenic factors 
to facilitate the epithelial-mesenchymal transition and migratory ability of tumor cells. Preclinically, strategies to alter the ratio of IL12 and IL-23 in the tumor microenvironment have been shown to synergize in combination with other anticancer therapies. Clinically, IL23 is overexpressed in a number of cancer types, which could potentially be targeted, particularly in those that display rich myeloid infiltrates. Although there are obvious caveats in the interpretation of mouse studies on the role of IL-12 and IL-23 in tumor biology, clinical studies have reported the favorable safety profile of anti-IL-12/23p40 mAbs (Ustekinumab). However, there was an increased risk in developing malignancies in psoriasis patients treated when high doses of anti-IL-12/23p40 mAbs were administered (Young and Czarnecki 2012). In contrast, major adverse cardiac events were observed in psoriasis patients treated with another anti-IL-12/23p40 mAb (Briakinumab) (Teng et al. 2015). To date, a number of IL-23specific antagonists have showed efficacy and safety in the treatment of psoriasis patients in late-stage clinical trials (Gordon et al. 2015; Teng et al. 2015). Should larger and longerterm trials show that neutralization of IL-23 impacts minimally on the risk of malignancies and infection development, anti-IL-23 could potentially be repositioned for use in immuno-oncology in combination with other immunotherapies.

\section{ACKNOWLEDGMENTS}

M.W.L.T. is supported by National Health and Medical Research Council of Australia (NHMRC) and Cancer Council of Queensland (CCQ) project grants. M.J.S. is supported by an NHMRC Project Grant, an NHMRC Senior Principal Research Fellowship, and the CCQ. J.Y. is supported by a University of Queensland International Scholarship and Queensland Institute of Medical Research (QIMR) Berghofer International Scholarship. M.J.S. has scientific research agreements with Bristol-Myers Squibb, Corvus Pharmaceuticals, and Aduro Biotech. The other authors declare that they have no conflicting financial interests.

\section{REFERENCES}

Aggarwal S, Ghilardi N, Xie MH, de Sauvage FJ, Gurney AL. 2003. Interleukin-23 promotes a distinct CD4 T cell activation state characterized by the production of interleukin-17. J Biol Chem 278: 1910-1914.

Airoldi I, Di Carlo E, Cocco C, Sorrentino C, Fais F, Cilli M, D'Antuono T, Colombo MP, Pistoia V. 2005. Lack of Il12rb2 signaling predisposes to spontaneous autoimmunity and malignancy. Blood 106: 3846-3853.

Awasthi A, Riol-Blanco L, Jager A, Korn T, Pot C, Galileos G, Bettelli E, Kuchroo VK, Oukka M. 2009. Cutting edge: IL23 receptor gfp reporter mice reveal distinct populations of IL-17-producing cells. J Immunol 182: 5904-5908.

Baird AM, Leonard J, Naicker KM, Kilmartin L, O’Byrne KJ, Gray SG. 2013. IL-23 is pro-proliferative, epigenetically regulated and modulated by chemotherapy in non-small cell lung cancer. Lung Cancer 79: 83-90.

Balhara J, Shan L, Zhang J, Muhuri A, Halayko AJ, Almiski MS, Doeing D, McConville J, Matzuk MM, Gounni AS. 2016. Pentraxin 3 deletion aggravates allergic inflammation through a TH17-dominant phenotype and enhanced CD4 T-cell survival. J Allergy Clin Immunol 139: $950-963$.

Banchereau J, Pascual V, O'Garra A. 2012. From IL-2 to IL37: The expanding spectrum of anti-inflammatory cytokines. Nat Immunol 13: 925-931.

Bernink JH, Peters CP, Munneke M, te Velde AA, Meijer SL, Weijer K, Hreggvidsdottir HS, Heinsbroek SE, Legrand N, Buskens CJ, et al. 2013. Human type 1 innate lymphoid cells accumulate in inflamed mucosal tissues. Nat Immunol 14: 221-229.

Blake SJ, Teng MW. 2014. Role of IL-17 and IL-22 in autoimmunity and cancer. Actas Dermosifiliogr 105: 41-50.

Blake SJ, Stannard K, Liu J, Allen S, Yong MC, Mittal D, Aguilera AR, Miles JJ, Lutzky VP, de Andrade LF, et al. 2016. Suppression of metastases using a new lymphocyte checkpoint target for cancer immunotherapy. Cancer Discov 6: 446-459.

Brahmachari S, Pahan K. 2009. Suppression of regulatory T cells by IL-12p 40 homodimer via nitric oxide. J Immunol 183: $2045-2058$

Brentano F, Ospelt C, Stanczyk J, Gay RE, Gay S, Kyburz D. 2009. Abundant expression of the interleukin (IL) $23 \mathrm{sub}$ unit p19, but low levels of bioactive IL23 in the rheumatoid synovium: Differential expression and Toll-like receptor-(TLR) dependent regulation of the IL23 subunits, p19 and p40, in rheumatoid arthritis. Ann Rheum Dis 68: $143-150$.

Cam C, Karagoz B, Muftuoglu T, Bigi O, Emirzeoglu L, Celik S, Ozgun A, Tuncel T, Top C. 2016. The inflammatory cytokine interleukin-23 is elevated in lung cancer, particularly small cell type. Contemp Oncol (Pozn) 20: 215219.

Cao X, Leonard K, Collins LI, Cai SF, Mayer JC, Payton JE, Walter MJ, Piwnica-Worms D, Schreiber RD, Ley TJ. 2009. Interleukin 12 stimulates IFN- $\boldsymbol{\gamma}$-mediated inhibition of tumor-induced regulatory $\mathrm{T}$-cell proliferation and enhances tumor clearance. Cancer Res 69: 8700-8709.

Chan IH, Jain R, Tessmer MS, Gorman D, Mangadu R, Sathe M, Vives F, Moon C, Penaflor E, Turner S, et al. 2014. Interleukin-23 is sufficient to induce rapid de novo gut 
J. Yan et al.

tumorigenesis, independent of carcinogens, through activation of innate lymphoid cells. Mucosal Immunol 7: 842-856.

Chang J, Voorhees TJ, Liu Y, Zhao Y, Chang CH. 2010. Interleukin-23 production in dendritic cells is negatively regulated by protein phosphatase 2A. Proc Natl Acad Sci 107: $8340-8345$.

Chang HH, Young SH, Sinnett-Smith J, Chou CE, Moro A, Hertzer KM, Hines OJ, Rozengurt E, Eibl G. 2015. Prostaglandin E2 activates the mTORC1 pathway through an $\mathrm{EP} 4 / \mathrm{cAMP} / \mathrm{PKA}-$ and $\mathrm{EP} 1 / \mathrm{Ca}^{2+}$-mediated mechanism in the human pancreatic carcinoma cell line PANC-1. Am J Physiol Cell Physiol 309: C639-C649.

Chen D, Li W, Liu S, Su Y, Han G, Xu C, Liu H, Zheng T, Zhou Y, Mao C. 2015. Interleukin-23 promotes the epithelial-mesenchymal transition of oesophageal carcinoma cells via the Wnt/ $\beta$-catenin pathway. Sci Rep 5: 8604

Chen F, Cao A, Yao S, Evans-Marin HL, Liu H, Wu W, Carlsen ED, Dann SM, Soong L, Sun J, et al. 2016. mTOR mediates IL-23 induction of neutrophil IL-17 and IL-22 production. J Immunol 196: 4390-4399.

Chiyo M, Shimozato O, Iizasa T, Fujisawa T, Tagawa M. 2004. Antitumor effects produced by transduction of dendritic cells-derived heterodimeric cytokine genes in murine colon carcinoma cells. Anticancer Res 24: 3763-3767.

Chognard G, Bellemare L, Pelletier AN, Dominguez-Punaro MC, Beauchamp C, Guyon MJ, Charron G, Morin N, Sivanesan D, Kuchroo V, et al. 2014. The dichotomous pattern of IL-12R and IL-23R expression elucidates the role of IL-12 and IL-23 in inflammation. PLoS ONE 9: e89092.

Chu H, Cao W, Chen W, Pan S, Xiao Y, Liu Y, Gu H, Guo W, $\mathrm{Xu} \mathrm{L,} \mathrm{Hu} \mathrm{Z,} \mathrm{et} \mathrm{al.} \mathrm{2012.} \mathrm{Potentially} \mathrm{functional} \mathrm{polymor-}$ phisms in IL-23 receptor and risk of esophageal cancer in a Chinese population. Int J Cancer 130: 1093-1097.

Ciric B, El-behi M, Cabrera R, Zhang GX, Rostami A. 2009. IL-23 drives pathogenic IL-17-producing $\mathrm{CD}^{+} \mathrm{T}$ cells. J Immunol 182: 5296-5305.

Cocco C, Canale S, Frasson C, Di Carlo E, Ognio E, Ribatti D, Prigione I, Basso G, Airoldi I. 2010. Interleukin-23 acts as antitumor agent on childhood B-acute lymphoblastic leukemia cells. Blood 116: 3887-3898.

Cocco C, Di Carlo E, Zupo S, Canale S, Zorzoli A, Ribatti D, Morandi F, Ognio E, Airoldi I. 2012. Complementary IL23 and IL-27 anti-tumor activities cause strong inhibition of human follicular and diffuse large B-cell lymphoma growth in vivo. Leukemia 26: 1365-1374.

Collison LW, Workman CJ, Kuo TT, Boyd K, Wang Y, Vignali KM, Cross R, Sehy D, Blumberg RS, Vignali DA. 2007. The inhibitory cytokine IL-35 contributes to regulatory T-cell function. Nature 450: 566-569.

Colombo MP, Trinchieri G. 2002. Interleukin-12 in antitumor immunity and immunotherapy. Cytokine Growth Factor Rev 13: 155-168.

Coquet JM, Chakravarti S, Kyparissoudis K, McNab FW, Pitt LA, McKenzie BS, Berzins SP, Smyth MJ, Godfrey DI. 2008. Diverse cytokine production by NKT cell subsets and identification of an IL-17-producing CD4 ${ }^{-}$NK1.1 $1^{-}$NKT cell population. Proc Natl Acad Sci 105: 11287-11292.

Cornelissen F, Aparicio Domingo P, Reijmers RM, Cupedo T. 2011. Activation and effector functions of human
$\mathrm{RORC}^{+}$innate lymphoid cells. Curr Opin Immunol 23: 361-367.

Cua DJ, Sherlock J, Chen Y, Murphy CA, Joyce B, Seymour B, Lucian L, To W, Kwan S, Churakova T, et al. 2003. Interleukin-23 rather than interleukin-12 is the critical cytokine for autoimmune inflammation of the brain. Nature 421: 744-748.

Dunn GP, Koebel CM, Schreiber RD. 2006. Interferons, immunity and cancer immunoediting. Nat Rev Immunol 6: 836-848.

Eisenring M, vom Berg J, Kristiansen G, Saller E, Becher B. 2010. IL-12 initiates tumor rejection via lymphoid tissueinducer cells bearing the natural cytotoxicity receptor NKp46. Nat Immunol 11: 1030-1038.

El-Behi M, Ciric B, Dai H, Yan Y, Cullimore M, Safavi F, Zhang GX, Dittel BN, Rostami A. 2011. The encephalitogenicity of $\mathrm{T}_{\mathrm{H}} 17$ cells is dependent on IL-1- and IL-23induced production of the cytokine GM-CSF. Nat Immunol 12: $568-575$.

Elinav E, Nowarski R, Thaiss CA, Hu B, Jin C, Flavell RA. 2013. Inflammation-induced cancer: Crosstalk between tumours, immune cells and microorganisms. Nat Rev Cancer 13: 759-771.

Eyerich S, Eyerich K, Cavani A, Schmidt-Weber C. 2010. IL17 and IL-22: Siblings, not twins. Trends Immunol 31: 354-361.

Fallarino F, Volpi C, Fazio F, Notartomaso S, Vacca C, Busceti C, Bicciato S, Battaglia G, Bruno V, Puccetti P, et al. 2010 Metabotropic glutamate receptor-4 modulates adaptive immunity and restrains neuroinflammation. Nat Med 16: 897-902.

Flores RR, Kim E, Zhou L, Yang C, Zhao J, Gambotto A, Robbins PD. 2015. IL-Y, a synthetic member of the IL-12 cytokine family, suppresses the development of type 1 diabetes in NOD mice. Eur J Immunol 45: 3114-3125.

Floss DM, Schroder J, Franke M, Scheller J. 2015. Insights into IL-23 biology: From structure to function. Cytokine Growth Factor Rev 26: 569-578.

Franke M, Schröder J, Monhasery N, Ackfeld T, Hummel TM, Rabe B, Garbers C, Becker-Pauly C, Floss DM, Scheller J. 2016. Human and murine interleukin 23 receptors are novel substrates for a disintegrin and metalloproteases ADAM10 and ADAM17. J Biol Chem 291: 10551-10561.

Fukuda M, Ehara M, Suzuki S, Ohmori Y, Sakashita H. 2010a. IL-23 promotes growth and proliferation in human squamous cell carcinoma of the oral cavity. Int $J$ Oncol 36: 1355-1365.

Fukuda M, Ehara M, Suzuki S, Sakashita H. 2010b. Expression of interleukin-23 and its receptors in human squamous cell carcinoma of the oral cavity. Mol Med Rep 3: 89-93.

Gaffen SL, Jain R, Garg AV, Cua DJ. 2014. The IL-23-IL-17 immune axis: From mechanisms to therapeutic testing. Nat Rev Immunol 14: 585-600.

Gangemi S, Minciullo P, Adamo B, Franchina T, Ricciardi GR, Ferraro M, Briguglio R, Toscano G, Saitta S, Adamo V. 2012. Clinical significance of circulating interleukin-23 as a prognostic factor in breast cancer patients. J Cell Biochem 113: 2122-2125. 
Ganzetti G, Rubini C, Campanati A, Zizzi A, Molinelli E, Rosa L, Simonacci F, Offidani A. 2015. IL-17, IL-23, and p73 expression in cutaneous melanoma: A pilot study. Melanoma Res 25: 232-238.

Gerosa F, Baldani-Guerra B, Lyakh LA, Batoni G, Esin S, Winkler-Pickett RT, Consolaro MR, De Marchi M, Giachino D, Robbiano A, et al. 2008. Differential regulation of interleukin 12 and interleukin 23 production in human dendritic cells. J Exp Med 205: 1447-1461.

Ghoreschi K, Laurence A, Yang XP, Tato CM, McGeachy MJ, Konkel JE, Ramos HL, Wei L, Davidson TS, Bouladoux $\mathrm{N}$, et al. 2010. Generation of pathogenic $\mathrm{T}_{\mathrm{H}} 17$ cells in the absence of TGF- $\beta$ signalling. Nature 467: 967-971.

Gillessen S, Carvajal D, Ling P, Podlaski FJ, Stremlo DL, Familletti PC, Gubler U, Presky DH, Stern AS, Gately MK. 1995. Mouse interleukin-12 (IL-12) p40 homodimer: A potent IL-12 antagonist. Eur J Immunol 25: 200-206.

Gordon KB, Duffin KC, Bissonnette R, Prinz JC, Wasfi Y, Li S, Shen YK, Szapary P, Randazzo B, Reich K. 2015. A phase 2 trial of guselkumab versus adalimumab for plaque psoriasis. $N$ Engl J Med 373: 136-144.

Grivennikov SI, Greten FR, Karin M. 2010. Immunity, inflammation, and cancer. Cell 140: 883-899.

Grivennikov SI, Wang K, Mucida D, Stewart CA, Schnabl B, Jauch D, Taniguchi K, Yu GY, Osterreicher CH, Hung KE et al. 2012. Adenoma-linked barrier defects and microbial products drive IL-23/IL-17-mediated tumour growth. Nature 491: 254-258.

Guenova E, Skabytska Y, Hoetzenecker W, Weindl G, Sauer K, Tham M, Kim KW, Park JH, Seo JH, Ignatova D, et al. 2015. IL-4 abrogates $\mathrm{T}_{\mathrm{H}} 17$ cell-mediated inflammation by selective silencing of IL-23 in antigen-presenting cells. Proc Natl Acad Sci 112: 2163-2168.

He S, Fei M, Wu Y, Zheng D, Wan D, Wang L, Li D. 2011. Distribution and clinical significance of Th17 cells in the tumor microenvironment and peripheral blood of pancreatic cancer patients. Int J Mol Sci 12: 7424-7437.

Hu J, Yuan X, Belladonna ML, Ong JM, Wachsmann-Hogiu S, Farkas DL, Black KL, Yu JS. 2006. Induction of potent antitumor immunity by intratumoral injection of interleukin 23-transduced dendritic cells. Cancer Res 66 8887-8896.

Hu P, Hu HD, Chen M, Peng ML, Tang L, Tang KF, Matsui M, Belladonna ML, Yoshimoto T, Zhang DZ, et al. 2009. Expression of interleukins-23 and 27 leads to successful gene therapy of hepatocellular carcinoma. Mol Immunol 46: $1654-1662$.

Hunter CA. 2005. New IL-12-family members: IL-23 and IL-27, cytokines with divergent functions. Nat Rev Immunol 5: 521-531.

Ivanov II, McKenzie BS, Zhou L, Tadokoro CE, Lepelley A, Lafaille JJ, Cua DJ, Littman DR. 2006. The orphan nuclear receptor ROR $\gamma t$ directs the differentiation program of proinflammatory IL-17 ${ }^{+}$T helper cells. Cell 126: $1121-$ 1133.

Jantschitsch C, Weichenthal M, Proksch E, Schwarz T, Schwarz A. 2012. IL-12 and IL-23 affect photocarcinogenesis differently. J Invest Dermatol 132: 1479-1486.

Kaiga T, Sato M, Kaneda H, Iwakura Y, Takayama T, Tahara H. 2007. Systemic administration of IL-23 induces potent antitumor immunity primarily mediated through Th1- type response in association with the endogenously expressed IL-12. J Immunol 178: 7571-7580.

Kan SH, Mancini G, Gallagher G. 2008. Identification and characterization of multiple splice forms of the human interleukin-23 receptor $\alpha$ chain in mitogen-activated leukocytes. Genes Immun 9: 631-639.

Kaplan DH, Shankaran V, Dighe AS, Stockert E, Aguet M, Old LJ, Schreiber RD. 1998. Demonstration of an interferon $\gamma$-dependent tumor surveillance system in immunocompetent mice. Proc Natl Acad Sci 95: 7556-7561.

Klein A, Schwartz H, Sagi-Assif O, Meshel T, Izraely S, Ben Menachem S, Bengaiev R, Ben-Shmuel A, Nahmias C, Couraud PO, et al. 2015. Astrocytes facilitate melanoma brain metastasis via secretion of IL-23. J Pathol 236: 116 127.

Koebel CM, Vermi W, Swann JB, Zerafa N, Rodig SJ, Old LJ, Smyth MJ, Schreiber RD. 2007. Adaptive immunity maintains occult cancer in an equilibrium state. Nature 450: 903-907.

Kohrt HE, Houot R, Weiskopf K, Goldstein MJ, Scheeren F, Czerwinski D, Colevas AD, Weng WK, Clarke MF, Carlson RW, et al. 2012. Stimulation of natural killer cells with a CD137-specific antibody enhances trastuzumab efficacy in xenotransplant models of breast cancer. J Clin Invest 122: $1066-1075$.

Kortylewski M, Xin H, Kujawski M, Lee H, Liu Y, Harris T, Drake C, Pardoll D, Yu H. 2009. Regulation of the IL-23 and IL-12 balance by Stat 3 signaling in the tumor microenvironment. Cancer Cell 15: 114-123.

Kulig P, Burkhard S, Mikita-Geoffroy J, Croxford AL, Hovelmeyer N, Gyulveszi G, Gorzelanny C, Waisman A, Borsig L, Becher B. 2016. IL17A-mediated endothelial breach promotes metastasis formation. Cancer Immunol Res 4: $26-32$.

Kvedaraite E, Lourda M, Idestrom M, Chen P, Olsson-Akefeldt S, Forkel M, Gavhed D, Lindforss U, Mjosberg J, Henter JI, et al. 2016. Tissue-infiltrating neutrophils represent the main source of IL-23 in the colon of patients with IBD. Gut 65: 1632-1641.

Lan F, Zhang L, Wu J, Zhang J, Zhang S, Li K, Qi Y, Lin P. 2011. IL-23/IL-23R: Potential mediator of intestinal tumor progression from adenomatous polyps to colorectal carcinoma. Int J Colorectal Dis 26: 1511-1518.

Langowski JL, Zhang X, Wu L, Mattson JD, Chen T, Smith K, Basham B, McClanahan T, Kastelein RA, Oft M. 2006. IL23 promotes tumour incidence and growth. Nature 442: 461-465.

Langrish CL, McKenzie BS, Wilson NJ, de Waal Malefyt R, Kastelein RA, Cua DJ. 2004. IL-12 and IL-23: Master regulators of innate and adaptive immunity. Immunol Rev 202: 96-105.

Langrish CL, Chen Y, Blumenschein WM, Mattson J, Basham B, Sedgwick JD, McClanahan T, Kastelein RA, Cua DJ. 2005. IL-23 drives a pathogenic $\mathrm{T}$ cell population that induces autoimmune inflammation. J Exp Med 201: 233-240.

Li J, Lau G, Chen L, Yuan YF, Huang J, Luk JM, Xie D, Guan XY. 2012. Interleukin 23 promotes hepatocellular carcinoma metastasis via NF- $\mathrm{KB}$ induced matrix metalloproteinase 9 expression. PLoS ONE 7: e46264.

Li J, Zhang L, Zhang J, Wei Y, Li K, Huang L, Zhang S, Gao B, Wang X, Lin P. 2013. Interleukin 23 regulates prolifera- 
J. Yan et al.

tion of lung cancer cells in a concentration-dependent way in association with the interleukin-23 receptor. Carcinogenesis 34: 658-666.

Li H, Hsu HC, Wu Q, Yang P, Li J, Luo B, Oukka M, Steele CH 3rd, Cua DJ, Grizzle WE, et al. 2014. IL-23 promotes TCR-mediated negative selection of thymocytes through the upregulation of IL-23 receptor and ROR $\gamma \mathrm{t}$. Nat Commun 5: 4259.

Liao C, Yu ZB, Meng G, Wang L, Liu QY, Chen LT, Feng SS, Tu HB, Li YF, Bai L. 2015. Association between Th17related cytokines and risk of non-small cell lung cancer among patients with or without chronic obstructive pulmonary disease. Cancer 121: 3122-3129.

Lindroos J, Svensson L, Norsgaard H, Lovato P, Moller K, Hagedorn PH, Olsen GM, Labuda T. 2011. IL-23-mediated epidermal hyperplasia is dependent on IL-6. J Invest Dermatol 131: 1110-1118.

Ling P, Gately MK, Gubler U, Stern AS, Lin P, Hollfelder K, Su C, Pan YC, Hakimi J. 1995. Human IL-12 p40 homodimer binds to the IL-12 receptor but does not mediate biologic activity. J Immunol 154: 116-127.

Liu J, Xiang Z, Ma X. 2004. Role of IFN regulatory factor-1 and IL-12 in immunological resistance to pathogenesis of $\mathrm{N}$-methyl- $\mathrm{N}$-nitrosourea-induced T lymphoma. J Immunol 173: 1184-1193.

Ljujic B, Radosavljevic G, Jovanovic I, Pavlovic S, Zdravkovic N, Milovanovic M, Acimovic L, Knezevic M, Bankovic D, Zdravkovic D, et al. 2010. Elevated serum level of IL-23 correlates with expression of VEGF in human colorectal carcinoma. Arch Med Res 41: 182-189.

Lo CH, Lee SC, Wu PY, Pan WY, Su J, Cheng CW, Roffler SR, Chiang BL, Lee CN, Wu CW, et al. 2003. Antitumor and antimetastatic activity of IL-23. J Immunol 171: 600-607.

Macho-Fernandez E, Koroleva EP, Spencer CM, Tighe M, Torrado E, Cooper AM, Fu YX, Tumanov AV. 2015. Lymphotoxin $\beta$ receptor signaling limits mucosal damage through driving IL-23 production by epithelial cells. $\mathrm{Mu}$ cosal Immunol 8: 403-413.

Majewski S, Jantschitsch C, Maeda A, Schwarz T, Schwarz A. 2010. IL-23 antagonizes UVR-induced immunosuppression through two mechanisms: Reduction of UVR-induced DNA damage and inhibition of UVR-induced regulatory T cells. J Invest Dermatol 130: 554-562.

Mancini G, Kan SH, Gallagher G. 2008. A novel insertion variant of the human IL-23 receptor- $\alpha$ chain transcript. Genes Immun 9: 566-569.

Mattner F, Fischer S, Guckes S, Jin S, Kaulen H, Schmitt E, Rude E, Germann T. 1993. The interleukin-12 subunit p40 specifically inhibits effects of the interleukin- 12 heterodimer. Eur J Immunol 23: 2202-2208.

Mei Z, Chen S, Chen C, Xiao B, Li F, Wang Y, Tao Z. 2015. Interleukin-23 facilitates thyroid cancer cell migration and invasion by inhibiting SOCS4 expression via microRNA-25. PLoS ONE 10: e0139456.

Moens E, Brouwer M, Dimova T, Goldman M, Willems F, Vermijlen D. 2011. IL-23R and TCR signaling drives the generation of neonatal V $\gamma 9 \mathrm{~V} \delta 2 \mathrm{~T}$ cells expressing high levels of cytotoxic mediators and producing IFN- $\gamma$ and IL-17. J Leukoc Biol 89: 743-752.

Muranski P, Restifo NP. 2013. Essentials of Th17 cell commitment and plasticity. Blood 121: 2402-2414.
Nakhle J, Pierron V, Bauchet AL, Plas P, Thiongane A, Meyer-Losic F, Schmidlin F. 2016. Tasquinimod modulates tumor-infiltrating myeloid cells and improves the antitumor immune response to PD-L1 blockade in bladder cancer. Oncoimmunology 5: e1145333.

Ngiow SF, Teng MWL, Smyth MJ. 2013. A balance of interleukin-12 and -23 in cancer. Trends Immunol 34: 548555.

Ngiow SF, Young A, Blake SJ, Hill GR, Yagita H, Teng MW, Korman AJ, Smyth MJ. 2016. Agonistic CD40 mAb-driven IL-12 reverses resistance to anti-PD1 in a T cell-rich tumor. Cancer Res 76: 6266-6277.

Oniki S, Nagai H, Horikawa T, Furukawa J, Belladonna ML, Yoshimoto T, Hara I, Nishigori C. 2006. Interleukin-23 and interleukin-27 exert quite different antitumor and vaccine effects on poorly immunogenic melanoma. Cancer Res 66: 6395-6404.

Paget C, Chow MT, Gherardin NA, Beavis PA, Uldrich AP, Duret H, Hassane M, Souza-Fonseca-Guimaraes F, Mogilenko DA, Staumont-Salle D, et al. 2015. CD $3^{\text {bright }}$ signals on $\gamma \delta \mathrm{T}$ cells identify IL-17A-producing $\mathrm{V} \gamma 6 \mathrm{~V} \delta 1^{+}$ T cells. Immunol Cell Biol 93: 198-212.

Pardoll DM. 2012. The blockade of immune checkpoints in cancer immunotherapy. Nat Rev Cancer 12: 252-264.

Prabhala RH, Pelluru D, Fulciniti M, Prabhala HK, Nanjappa P, Song W, Pai C, Amin S, Tai YT, Richardson PG, et al. 2010. Elevated IL-17 produced by $\mathrm{T}_{\mathrm{H}} 17$ cells promotes myeloma cell growth and inhibits immune function in multiple myeloma. Blood 115: 5385-5392.

Pylayeva-Gupta Y. 2016. Molecular pathways: Interleukin35 in autoimmunity and cancer. Clin Cancer Res 22: 4973-4978.

Qian X, Cao S, Yang G, Pan Y, Yin C, Chen X, Zhu Y, Zhuang Y, Shen Y, Hu Z. 2013a. Potentially functional polymorphism in IL-23 receptor and risk of acute myeloid leukemia in a Chinese population. PLoS ONE 8: e55473.

Qian X, Gu L, Ning H, Zhang Y, Hsueh EC, Fu M, Hu X, Wei L, Hoft DF, Liu J. 2013b. Increased Th17 cells in the tumor microenvironment is mediated by IL-23 via tumor-secreted PGE $\mathrm{PG}_{2}$ J Immunol 190: 5894-5902.

Rachitskaya AV, Hansen AM, Horai R, Li Z, Villasmil R, Luger D, Nussenblatt RB, Caspi RR. 2008. Cutting edge: NKT cells constitutively express IL-23 receptor and ROR $\gamma \mathrm{t}$ and rapidly produce IL-17 upon receptor ligation in an IL-6-independent fashion. J Immunol 180: $5167-5171$.

Ramnath D, Tunny K, Hohenhaus DM, Pitts CM, Bergot AS, Hogarth PM, Hamilton JA, Kapetanovic R, Sturm RA, Scholz GM, et al. 2015. TLR3 drives IRF6-dependent IL-23p19 expression and p19/EBI3 heterodimer formation in keratinocytes. Immunol Cell Biol 93: 771-779.

Raverdeau M, Breen CJ, Misiak A, Mills KH. 2016. Retinoic acid suppresses IL-17 production and pathogenic activity of $\gamma \delta$ T cells in CNS autoimmunity. Immunol Cell Biol 94: $763-773$.

Reay J, Gambotto A, Robbins PD. 2012. The antitumor effects of adenoviral-mediated, intratumoral delivery of interleukin 23 require endogenous IL-12. Cancer Gene Ther 19: 135-143.

Sabat R, Ouyang W, Wolk K. 2013. Therapeutic opportunities of the IL-22-IL-22R1 system. Nat Rev Drug Discov 13: $21-38$. 
Roles of IL-12 and IL-23 in Cancer

Sarin R, Wu X, Abraham C. 2011. Inflammatory disease protective R381Q IL23 receptor polymorphism results in decreased primary $\mathrm{CD}^{+}$and $\mathrm{CD}^{+}$human T-cell functional responses. Proc Natl Acad Sci 108: 9560-9565.

Schreiber RD, Old LJ, Smyth MJ. 2011. Cancer immunoediting: Integrating immunity's roles in cancer suppression and promotion. Science 331: 1565-1570.

Shan BE, Hao JS, Li QX, Tagawa M. 2006. Antitumor activity and immune enhancement of murine interleukin-23 expressed in murine colon carcinoma cells. Cell Mol Immunol 3: 47-52.

Shapiro M, Nandi B, Pai C, Samur MK, Pelluru D, Fulciniti M, Prabhala RH, Munshi NC, Gold JS. 2016. Deficiency of IL-17A, but not the prototypical Th17 transcription factor ROR $\gamma \mathrm{t}$, decreases murine spontaneous intestinal tumorigenesis. Cancer Immunol Immunother 65: 13-24.

Sheikh SZ, Matsuoka K, Kobayashi T, Li F, Rubinas T, Plevy SE. 2010. Cutting edge: IFN- $\gamma$ is a negative regulator of IL-23 in murine macrophages and experimental colitis. J Immunol 184: 4069-4073.

Sheikh SZ, Kobayashi T, Matsuoka K, Onyiah JC, Plevy SE. 2011. Characterization of an interferon-stimulated response element (ISRE) in the Il23a promoter. J Biol Chem 286: 1174-1180.

Shen P, Roch T, Lampropoulou V, O'Connor RA, Stervbo U, Hilgenberg E, Ries S, Dang VD, Jaimes Y, Daridon C, et al. 2014. IL-35-producing B cells are critical regulators of immunity during autoimmune and infectious diseases. Nature 507: 366-370.

Shimozato O, Ugai S, Chiyo M, Takenobu H, Nagakawa H, Wada A, Kawamura K, Yamamoto H, Tagawa M. 2006. The secreted form of the p40 subunit of interleukin (IL)12 inhibits IL-23 functions and abrogates IL-23-mediated antitumour effects. Immunology 117: 22-28.

Sieve AN, Meeks KD, Lee S, Berg RE. 2010. A novel immunoregulatory function for IL-23: Inhibition of IL-12-dependent IFN- $\gamma$ production. Eur J Immunol 40: 22362247.

Smyth MJ, Thia KY, Street SE, Cretney E, Trapani JA, Taniguchi M, Kawano T, Pelikan SB, Crowe NY, Godfrey DI. 2000. Differential tumor surveillance by natural killer (NK) and NKT cells. J Exp Med 191: 661-668.

Smyth MJ, Ngiow SF, Ribas A, Teng MW. 2016. Combination cancer immunotherapies tailored to the tumour microenvironment. Nat Rev Clin Oncol 13: 143-158.

Stanilov N, Miteva L, Deliysky T, Jovchev J, Stanilova S. 2010. Advanced colorectal cancer is associated with enhanced IL-23 and IL-10 serum levels. Lab Med 41: 159163.

Street SE, Trapani JA, MacGregor D, Smyth MJ. 2002. Suppression of lymphoma and epithelial malignancies effected by interferon $\gamma$. J Exp Med 196: 129-134.

Sutton CE, Lalor SJ, Sweeney CM, Brereton CF, Lavelle EC, Mills KH. 2009. Interleukin-1 and IL-23 induce innate IL-17 production from $\gamma \delta$ T cells, amplifying Th17 responses and autoimmunity. Immunity 31: 331-341.

Suzuki H, Ogawa H, Miura K, Haneda S, Watanabe K, Ohnuma S, Sasaki H, Sase T, Kimura S, Kajiwara T, et al. 2012. IL-23 directly enhances the proliferative and invasive activities of colorectal carcinoma. Oncol Lett 4: 199204.
Tang XZ, Jo J, Tan AT, Sandalova E, Chia A, Tan KC, Lee KH, Gehring AJ, De Libero G, Bertoletti A. 2013. IL-7 licenses activation of human liver intrasinusoidal mucosal-associated invariant T cells. J Immunol 190: 3142-3152.

Taylor PR, Roy S, Leal SM Jr, Sun Y, Howell SJ, Cobb BA, Li X, Pearlman E. 2014. Activation of neutrophils by autocrine IL-17A-IL-17RC interactions during fungal infection is regulated by IL-6, IL-23, ROR $\gamma \mathrm{t}$ and dectin-2. Nat Immunol 15: 143-151.

Teng MW, Andrews DM, McLaughlin N, von Scheidt B, Ngiow SF, Moller A, Hill GR, Iwakura Y, Oft M, Smyth MJ. 2010. IL-23 suppresses innate immune response independently of IL-17A during carcinogenesis and metastasis. Proc Natl Acad Sci 107: 8328-8333.

Teng MW, von Scheidt B, Duret H, Towne JE, Smyth MJ. 2011. Anti-IL-23 monoclonal antibody synergizes in combination with targeted therapies or IL-2 to suppress tumor growth and metastases. Cancer Res 71: 20772086.

Teng MW, Vesely MD, Duret H, McLaughlin N, Towne JE, Schreiber RD, Smyth MJ. 2012. Opposing roles for IL-23 and IL-12 in maintaining occult cancer in an equilibrium state. Cancer Res 72: 3987-3996.

Teng MW, Bowman EP, McElwee JJ, Smyth MJ, Casanova JL, Cooper AM, Cua DJ. 2015. IL-12 and IL-23 cytokines: From discovery to targeted therapies for immune-mediated inflammatory diseases. Nat Med 21: 719-729.

Trinchieri G. 2003. Interleukin-12 and the regulation of innate resistance and adaptive immunity. Nat Rev Immunol 3: 133-146.

Tugues S, Burkhard SH, Ohs I, Vrohlings M, Nussbaum K, Vom Berg J, Kulig P, Becher B. 2015. New insights into IL12-mediated tumor suppression. Cell Death Differ 22: 237-246.

Vignali DA, Kuchroo VK. 2012. IL-12 family cytokines: Immunological playmakers. Nat Immunol 13: 722-728.

Vom Berg J, Vrohlings M, Haller S, Haimovici A, Kulig P, Sledzinska A, Weller M, Becher B. 2013. Intratumoral IL12 combined with CTLA-4 blockade elicits T cell-mediated glioma rejection. J Exp Med 210: 2803-2811.

von Scheidt B, Leung PS, Yong MC, Zhang Y, Towne JE, Smyth MJ, Teng MW. 2014. Combined anti-CD40 and anti-IL-23 monoclonal antibody therapy effectively suppresses tumor growth and metastases. Cancer Res 74: 2412-2421.

Waibler Z, Kalinke U, Will J, Juan MH, Pfeilschifter JM, Radeke HH. 2007. TLR-ligand stimulated interleukin23 subunit expression and assembly is regulated differentially in murine plasmacytoid and myeloid dendritic cells. Mol Immunol 44: 1483-1489.

Wang RX, Yu CR, Mahdi RM, Egwuagu CE. 2012. Novel IL27p28/IL12p40 cytokine suppressed experimental autoimmune uveitis by inhibiting autoreactive Th1/Th17 cells and promoting expansion of regulatory T cells. J Biol Chem 287: 36012-36021.

Wang JM, Shi L, Ma CJ, Ji XJ, Ying RS, Wu XY, Wang KS, Li G, Moorman JP, Yao ZQ. 2013. Differential regulation of interleukin-12 (IL-12)/IL-23 by Tim-3 drives $\mathrm{T}_{\mathrm{H}} 17$ cell development during hepatitis $C$ virus infection. J Virol 87: $4372-4383$.

Wang P, Yang B, Zhou B, Zhang J, Li S, Jiang J, Sun Z, Jin F. 2016. Distribution and expression profiles of dendritic 
J. Yan et al.

cell subpopulations in human bladder cancer. Int J Clin Exp Pathol 9: 7180-7187.

Wilke CM, Bishop K, Fox D, Zou W. 2011a. Deciphering the role of Th17 cells in human disease. Trends Immunol 32: 603-611.

Wilke CM, Kryczek I, Wei S, Zhao E, Wu K, Wang G, Zou W. 2011b. Th17 cells in cancer: Help or hindrance? Carcinogenesis 32: 643-649.

Wolf AM, Rumpold H, Reimer D, Marth C, Zeimet AG, Wolf D. 2010. High IL-12 p35 and IL-23 p19 mRNA expression is associated with superior outcome in ovarian cancer. Gynecol Oncol 118: 244-250.

Wu S, Rhee KJ, Albesiano E, Rabizadeh S, Wu X, Yen HR, Huso DL, Brancati FL, Wick E, McAllister F, et al. 2009. A human colonic commensal promotes colon tumorigenesis via activation of Thelper type $17 \mathrm{~T}$ cell responses. Nat Med 15: 1016-1022.

Wu L, Diny NL, Ong S, Barin JG, Hou X, Rose NR, Talor MV, Čiháková D. 2016. Pathogenic IL-23 signaling is required to initiate GM-CSF-driven autoimmune myocarditis in mice. Eur J Immunol 46: 582-592.

Xu Y, Liu Y, Pan S, Liu L, Liu J, Zhai X, Shen H, Hu Z. 2013. IL-23R polymorphisms, HBV infection, and risk of hepatocellular carcinoma in a high-risk Chinese population. J Gastroenterol 48: 125-131.

Ye Z, Deng B, Wang C, Zhang D, Kijlstra A, Yang P. 2016. Decreased $\mathrm{B}$ and $\mathrm{T}$ lymphocyte attenuator in Behcet's disease may trigger abnormal Th17 and Th1 immune responses. Sci Rep 6: 20401.

Yen D, Cheung J, Scheerens H, Poulet F, McClanahan T, McKenzie B, Kleinschek MA, Owyang A, Mattson J, Blumenschein W, et al. 2006. IL-23 is essential for T cellmediated colitis and promotes inflammation via IL-17 and IL-6. J Clin Invest 116: 1310-1316.

Yoshida H, Hunter CA. 2015. The immunobiology of interleukin-27. Annu Rev Immunol 33: 417-443.

Young L, Czarnecki D. 2012. The rapid onset of multiple squamous cell carcinomas in two patients commenced on ustekinumab as treatment of psoriasis. Australas $J$ Dermatol 53: 57-60.
Young MRI, Levingston CA, Johnson SD. 2016. Treatment to sustain a Th17-type phenotype to prevent skewing toward Treg and to limit premalignant lesion progression to cancer. Int J Cancer 138: 2487-2498.

Yuan X, Hu J, Belladonna ML, Black KL, Yu JS. 2006. Interleukin-23-expressing bone marrow-derived neural stemlike cells exhibit antitumor activity against intracranial glioma. Cancer Res 66: 2630-2638.

Zhang XY, Zhang HJ, Zhang Y, Fu YJ, He J, Zhu LP, Wang SH, Liu L. 2006. Identification and expression analysis of alternatively spliced isoforms of human interleukin- 23 receptor gene in normal lymphoid cells and selected tumor cells. Immunogenetics 57: 934-943.

Zhang B, Rong G, Wei H, Zhang M, Bi J, Ma L, Xue X, Wei G, Liu X, Fang G. 2008. The prevalence of Th17 cells in patients with gastric cancer. Biochem Biophys Res Commun 374: 533-537.

Zhang Y, Ma CJ, Ni L, Zhang CL, Wu XY, Kumaraguru U, Li CF, Moorman JP, Yao ZQ. 2011a. Cross-talk between programmed death-1 and suppressor of cytokine signaling-1 in inhibition of IL-12 production by monocytes/macrophages in hepatitis C virus infection. J Immunol 186: 3093-3103.

Zhang Y, Ma CJ, Wang JM, Ji XJ, Wu XY, Jia ZS, Moorman JP, Yao ZQ. 2011b. Tim-3 negatively regulates IL-12 expression by monocytes in HCV infection. PLoS ONE 6: e19664.

Zhang L, Li J, Li L, Zhang J, Wang X, Yang C, Li Y, Lan F, Lin P. 2014. IL-23 selectively promotes the metastasis of colorectal carcinoma cells with impaired Socs 3 expression via the STAT5 pathway. Carcinogenesis 35: 1330-1340.

Zindl CL, Lai JF, Lee YK, Maynard CL, Harbour SN, Ouyang W, Chaplin DD, Weaver CT. 2013. IL-22-producing neutrophils contribute to antimicrobial defense and restitution of colonic epithelial integrity during colitis. Proc Natl Acad Sci 110: 12768-12773.

Zou W, Restifo NP. 2010. $\mathrm{T}_{\mathrm{H}} 17$ cells in tumour immunity and immunotherapy. Nat Rev Immunol 10: 248-256.

Zundler S, Neurath MF. 2015. Interleukin-12: Functional activities and implications for disease. Cytokine Growth Factor Rev 26: 559-568. 


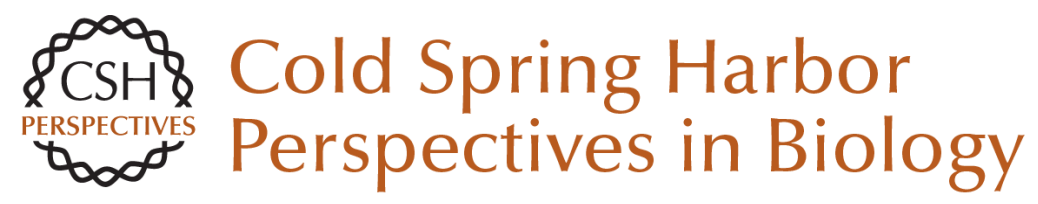

\section{Interleukin (IL)-12 and IL-23 and Their Conflicting Roles in Cancer}

Juming Yan, Mark J. Smyth and Michele W.L. Teng

Cold Spring Harb Perspect Biol 2018; doi: 10.1101/cshperspect.a028530 originally published online July 17,2017

\section{Subject Collection Cytokines}

Interleukin (IL)-33 and the IL-1 Family of Cytokines -Regulators of Inflammation and Tissue Homeostasis

Ajithkumar Vasanthakumar and Axel Kallies

Targeting IL-10 Family Cytokines for the Treatment of Human Diseases Xiaoting Wang, Kit Wong, Wenjun Ouyang, et al.

Cytokine-Mediated Regulation of CD8 T-Cell Responses During Acute and Chronic Viral Infection

Masao Hashimoto, Se Jin Im, Koichi Araki, et al.

Cytokines in Cancer Immunotherapy

Thomas A. Waldmann

The Tumor Necrosis Factor Family: Family Conventions and Private Idiosyncrasies David Wallach

The Interferon (IFN) Class of Cytokines and the IFN Regulatory Factor (IRF) Transcription Factor Family

Hideo Negishi, Tadatsugu Taniguchi and Hideyuki Yanai
Interferon $\gamma$ and Its Important Roles in Promoting and Inhibiting Spontaneous and Therapeutic Cancer Immunity

Elise Alspach, Danielle M. Lussier and Robert D. Schreiber

Inflammasome-Dependent Cytokines at the Crossroads of Health and Autoinflammatory Disease

Hanne Van Gorp, Nina Van Opdenbosch and Mohamed Lamkanfi

Innate Lymphoid Cells (ILCs): Cytokine Hubs Regulating Immunity and Tissue Homeostasis Maho Nagasawa, Hergen Spits and Xavier Romero Ros

T Helper Cell Differentiation, Heterogeneity, and

Plasticity Jinfang Zhu

Development, Diversity, and Function of Dendritic Cells in Mouse and Human

David A. Anderson III, Kenneth M. Murphy and Carlos G. Briseño

Cytokines and Long Noncoding RNAs Susan Carpenter and Katherine A. Fitzgerald

For additional articles in this collection, see http://cshperspectives.cshlp.org/cgi/collection/

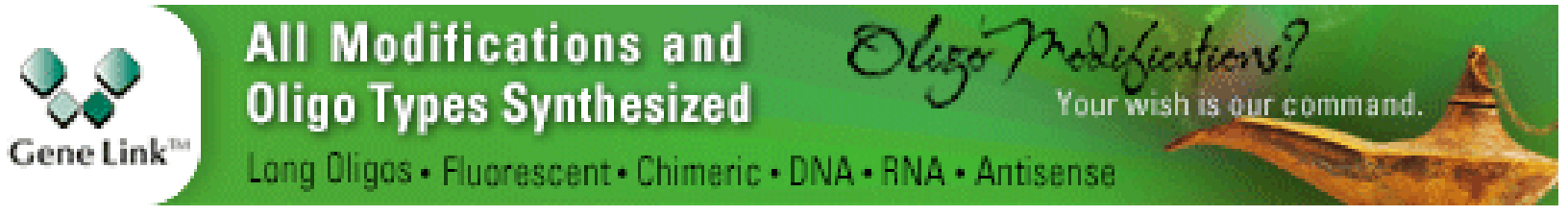


Role of the $\beta$ Common $(\beta \mathrm{c})$ Family of Cytokines in Health and Disease

Timothy R. Hercus, Winnie L. T. Kan, Sophie E. Broughton, et al.

Interleukin (IL)-12 and IL-23 and Their Conflicting Roles in Cancer Juming Yan, Mark J. Smyth and Michele W.L. Teng
Negative Regulation of Cytokine Signaling in Immunity

Akihiko Yoshimura, Minako Ito, Shunsuke Chikuma, et al.

Cancer Inflammation and Cytokines

Maria Rosaria Galdiero, Gianni Marone and Alberto Mantovani

For additional articles in this collection, see http://cshperspectives.cshlp.org/cgi/collection/

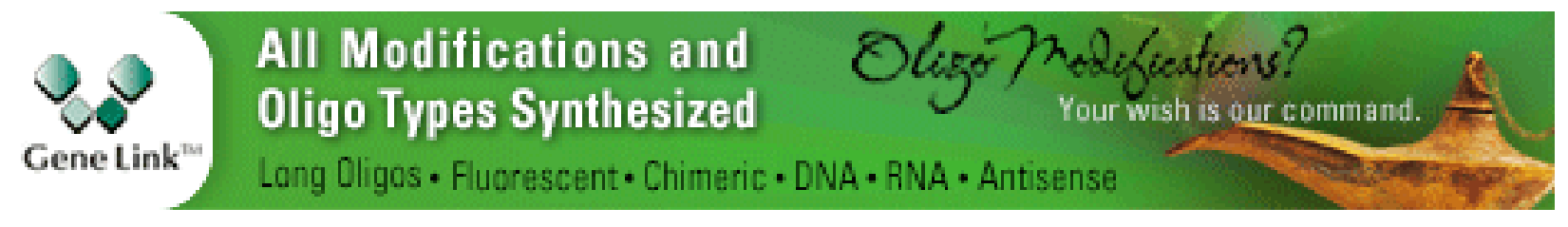

Copyright @ 2018 Cold Spring Harbor Laboratory Press; all rights reserved 